\title{
Cyprus: 2009 Article IV Consultation-Staff Report; Public Information Notice on the Executive Board Discussion; and Statement by the Executive Director for Cyprus
}

Under Article IV of the IMF's Articles of Agreement, the IMF holds bilateral discussions with members, usually every year. In the context of the 2009 Article IV consultation with Cyprus, the following documents have been released and are included in this package:

- $\quad$ The staff report for the 2009 Article IV consultation, prepared by a staff team of the IMF, following discussions that ended on June 29, 2009, with the officials of Cyprus on economic developments and policies. Based on information available at the time of these discussions, the staff report was completed on July 21, 2009. The views expressed in the staff report are those of the staff team and do not necessarily reflect the views of the Executive Board of the IMF.

- $\quad$ A Public Information Notice (PIN) summarizing the views of the Executive Board as expressed during its August 5, 2009 discussion of the staff report that concluded the Article IV consultation.

- $\quad$ A statement by the Executive Director for Cyprus.

The policy of publication of staff reports and other documents allows for the deletion of market-sensitive information.

Copies of this report are available to the public from

International Monetary Fund $\bullet$ Publication Services

$70019^{\text {th }}$ Street, N.W. $\bullet$ Washington, D.C. 20431

Telephone: (202) 623-7430 • Telefax: (202) 623-7201

E-mail: publications@imf.org•Internet: http://www.imf.org

\section{International Monetary Fund \\ Washington, D.C.}



INTERNATIONAL MONETARY FUND

\section{CYPRUS}

\section{Staff Report for the 2009 Article IV Consultation}

Prepared by the Staff Representatives for the 2009 Consultation with Cyprus

Approved by Ajai Chopra and Ranil Salgado

July 21, 2009

\section{Executive Summary}

Context: The global crisis has started to affect Cyprus. The overheating of the economy in 2007-08 has given rise to vulnerabilities, notably, a highly leveraged private sector, large current account deficits, and a large exposure of banks to property prices. While the financial sector is holding up, its size and concentration could pose systemic risks. The expected economic downturn will worsen credit risk in banks and, under current policies, pose concerns regarding fiscal sustainability. The steady deterioration in competitiveness threatens medium-term growth and viability.

Staff views: Early detection and intervention will be key to preventing financial sector problems from escalating to systemic proportions. The supervisors' ability to preempt and manage a crisis should be bolstered. A $1 / 2-3 / 4$ percent a year public consumption-based fiscal adjustment would be necessary to meet the government's objective of medium-term budget balance and to avoid an unsustainable public debt-deficit cycle. Wage bill control, public administration reform, and targeted social support would be desirable. The recent pension reform, while commendable, may need to be bolstered in future. The government's structural reform program should be implemented speedily to shore up competitiveness. The inflation-indexed wage adjustment mechanism (COLA) should ideally be eliminated or at least better targeted.

Authorities' views: The government expects to be able to meet its fiscal objectives without altering current plans. Recommendations to improve financial sector stability were well received. Reforming the COLA is unlikely to be on the policy agenda.

Mission team: A. Banerji (head), P. Sodsriwiboon (both EUR), and Y. Lu (MCM), joined by K. Driessen (MCM) to discuss the conclusions of the 2008 Financial Sector Assessment Program (FSAP). Mr. Galac (OED) also attended.

Interlocutors: Minister of Finance Stavrakis, Governor Orphanides, senior public sector and parliamentary officials, private banks and businesses, labor unions, and academia.

Outreach: A press conference was held and the concluding statement published. 


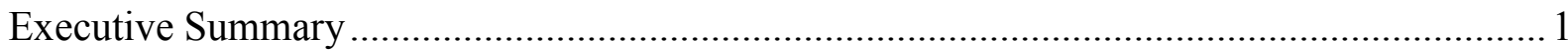

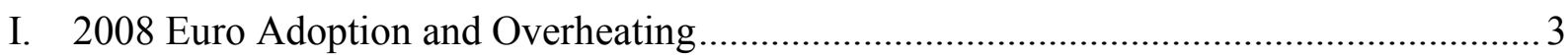

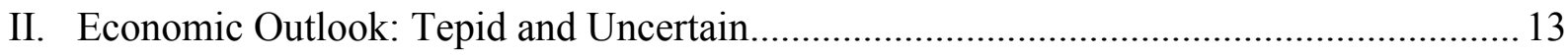

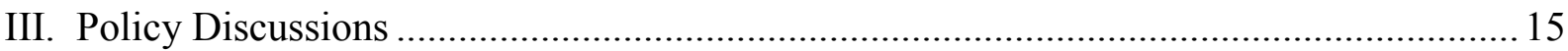

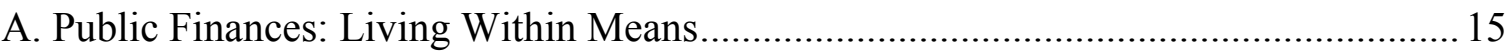

B. Financial Sector: Prevention is Easier Than a Cure.................................................. 18

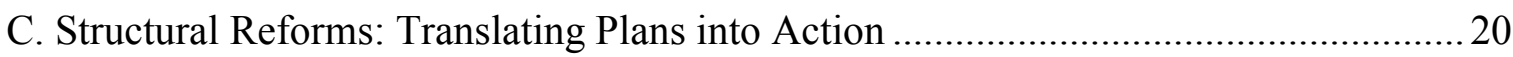

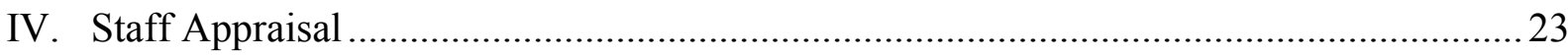

Figures

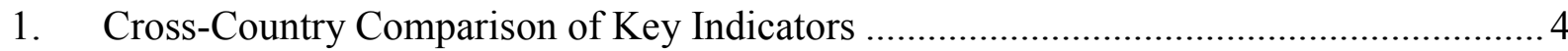

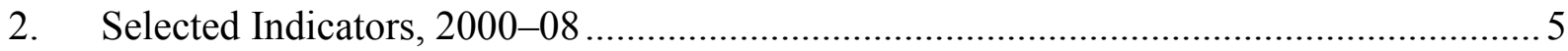

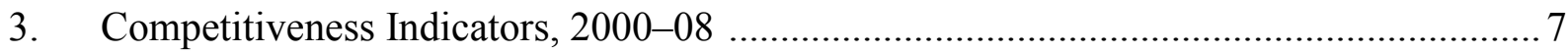

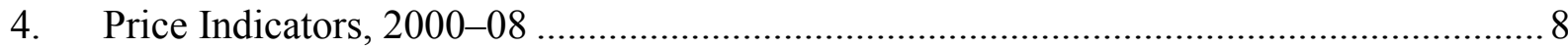

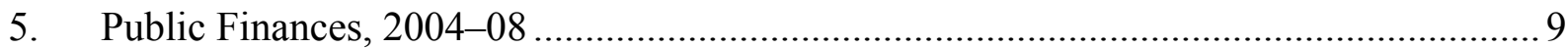

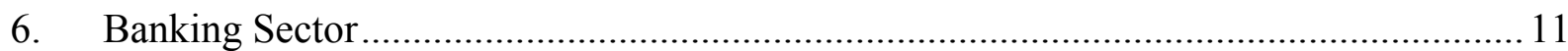

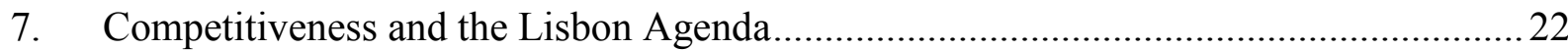

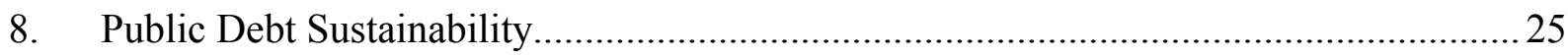

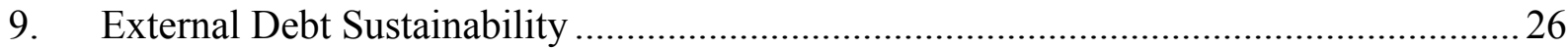

\section{Tables}

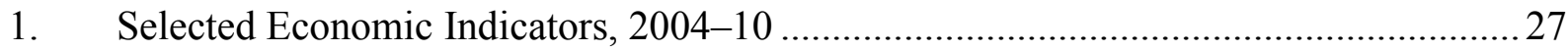

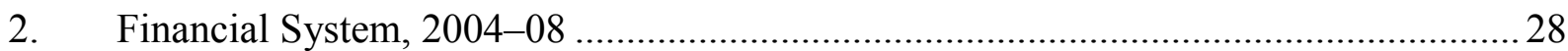

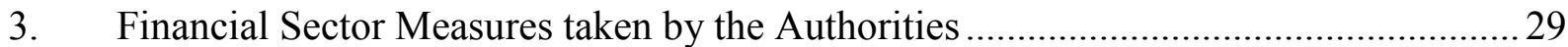

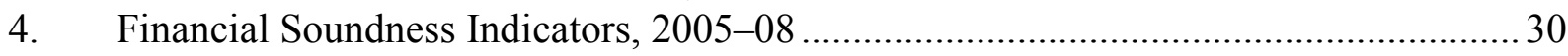

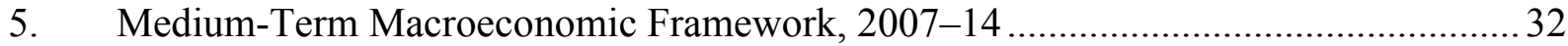

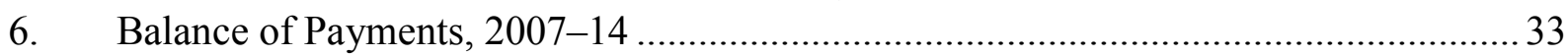

7. General Government Accounts, 2007-14 ……………................................................ 34 


\section{2008: EURO ADOPTION AND OVERHEATING ${ }^{1}$}

1. Cyprus appears to be weathering the global crisis reasonably well (Figure 1). It recorded positive growth in the first quarter of 2009, well above the euro area average, and is among those that have not required public capital injections into its financial sector. The relatively benign impact of the crisis is due, in part, to the elimination of exchange rate risk following euro adoption and to conservative financial sector practices, limited exposure to toxic assets and strict supervision. The latter has preserved confidence in the financial system which has not only prevented capital outflows, but also attracted capital from distressed economies in the region. A domestic demand-based growth - supported by recent large real wage increases - and a relatively small contribution of manufacturing exports has also insulated the economy from a deterioration in partner country growth. Past budget surpluses, low public debt, and the long-awaited enactment of pension reforms have sustained investor confidence, as evidenced by a successful sovereign bond issue in June 2009. ${ }^{2}$

\section{Nonetheless, the overheating of the economy during 2007-08 has given rise to} vulnerabilities (Figure 2, Table 1). Growth was largely credit-financed and coincided with strong real wage growth, low unemployment, significant FDI in the property market, and an improving business climate. Rapid credit growth was driven by excess liquidity in the banking system as the Central Bank of Cyprus (CBC) lowered interest rates, and reserve and prudential liquidity requirements on euro deposits following the mid-2007 decision to enter the eurozone on January $1,2008 .{ }^{3}$ Coincidentally fiscal policy was also relaxed (paragraph 5). Credit was channeled to the property market driven by rising demand for undeveloped land in anticipation of a 15 percent VAT on land starting in 2008. As a

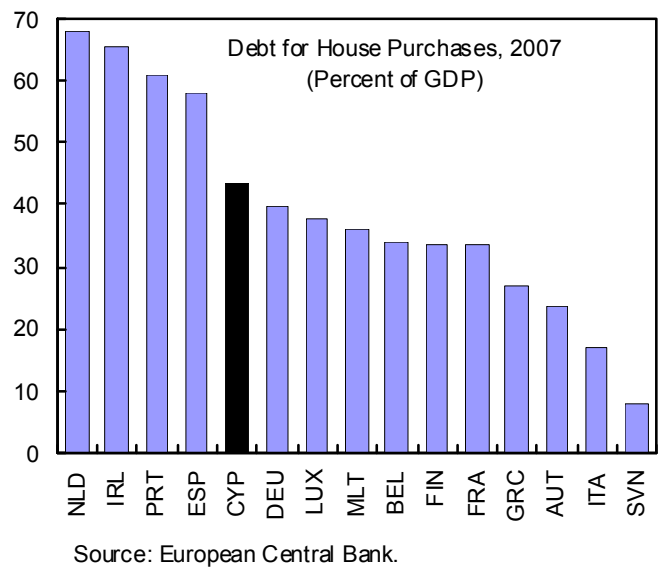

\footnotetext{
${ }^{1}$ This report reflects discussions with the policymakers of the Republic of Cyprus. It does not cover the areas not under the effective control of the government of the Republic of Cyprus and assumes no change in the status quo.

${ }^{2} \mathrm{~A} € 1 \frac{1 / 2}{2}$ billion five-year bond — $3 / 4$ of the government's financing needs for 2009 — was successfully issued in June.

${ }^{3}$ The $\mathrm{CBC}$ reduced the minimum liquidity requirement from 75 to 70 percent for all foreign currency deposits. Credit growth was also supported by an inflow of non-resident deposits (largely from CIS countries) in response to financial liberalization, and growing competition for market share following the entry of foreign banks into Cyprus.
} 
Figure 1. Cyprus: Cross-Country Comparison of Key Indicators (Percent of GDP, unless indicated otherwise)

Cyprus has a large current account deficit...

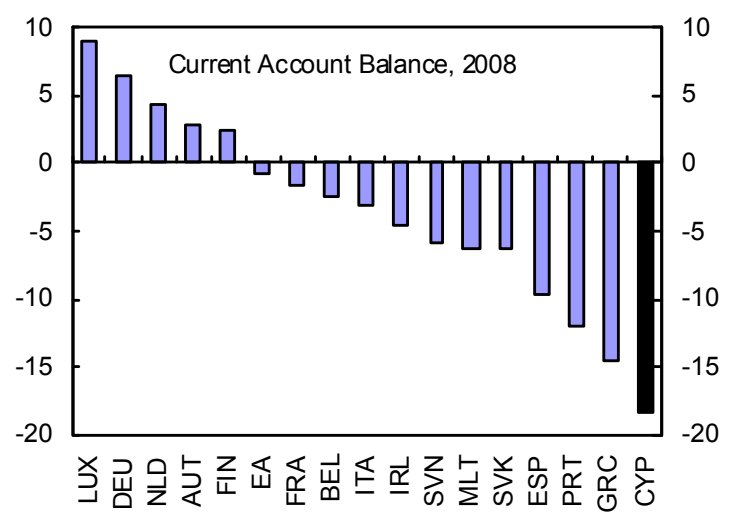

However, the economy continues to grow,

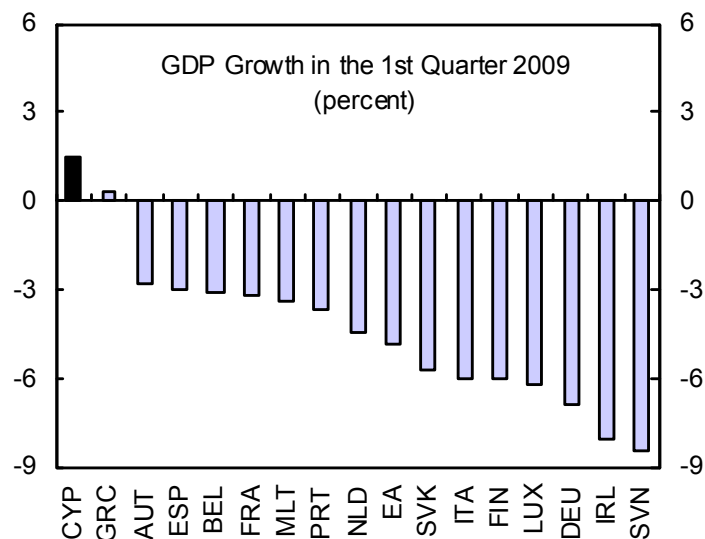

... and external debt.

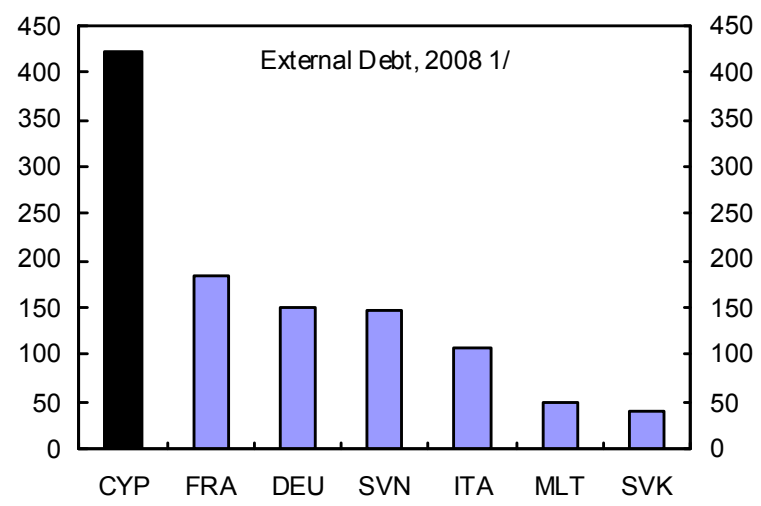

...public finances are relatively strong,

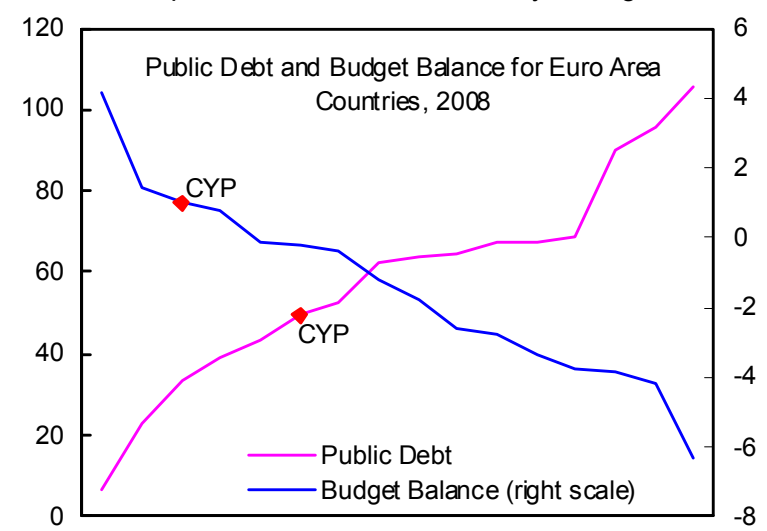

....and the IIP is positive.

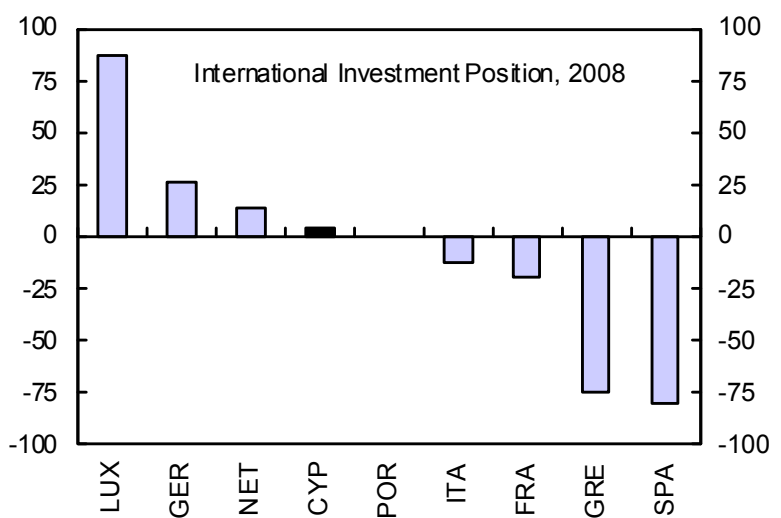

Banks have not needed public capital injections.

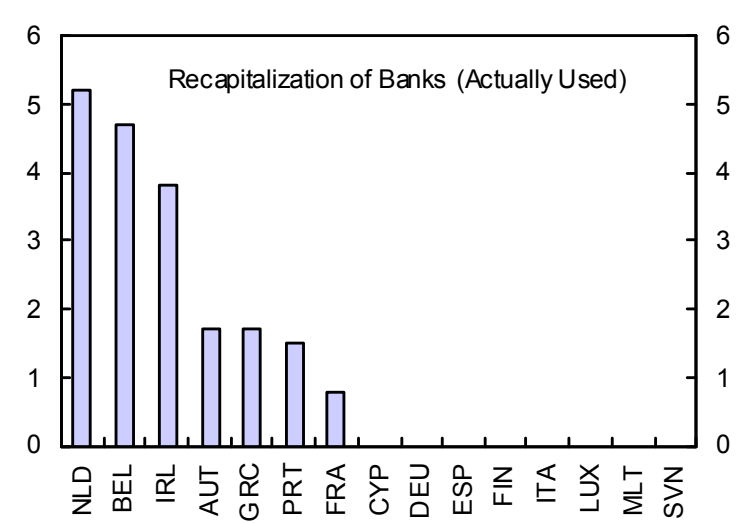

Sources: Bloomberg; Eurostat; Central Bank of Cyprus; and IMF staff calculations. 1/ External debt including non-resident deposits in domestic banks. 
Figure 2. Cyprus: Selected Indicators, 2000-08 (Year-on-year percent change, unless otherwise indicated)

Growth has been faster than the euro area...

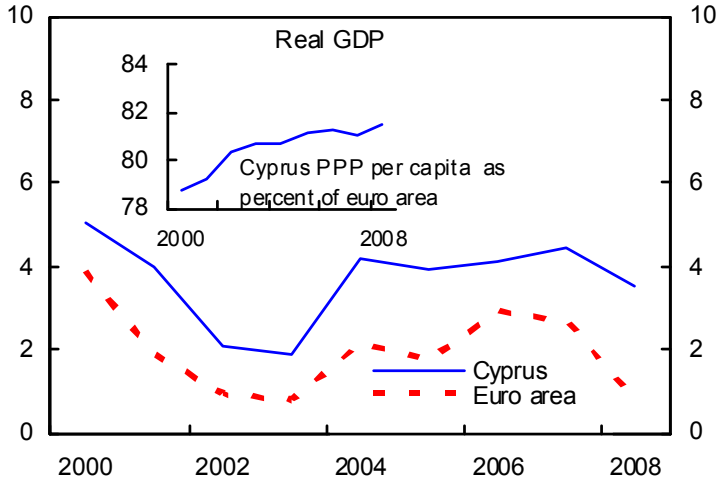

...which was spurred by credit growth.

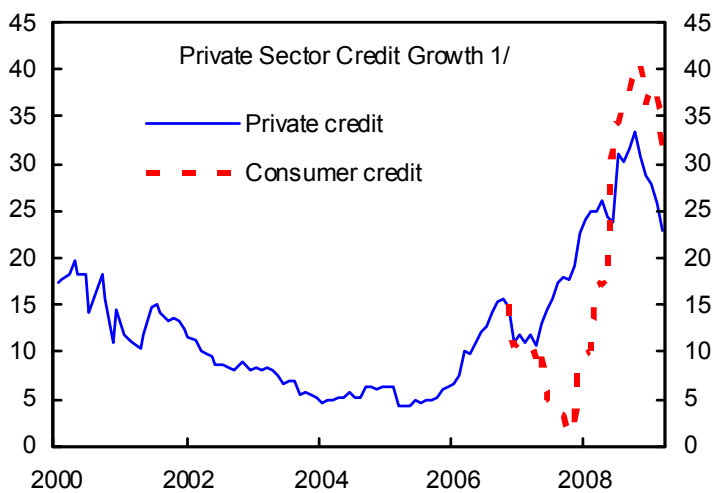

the current account deficit widened sharply...

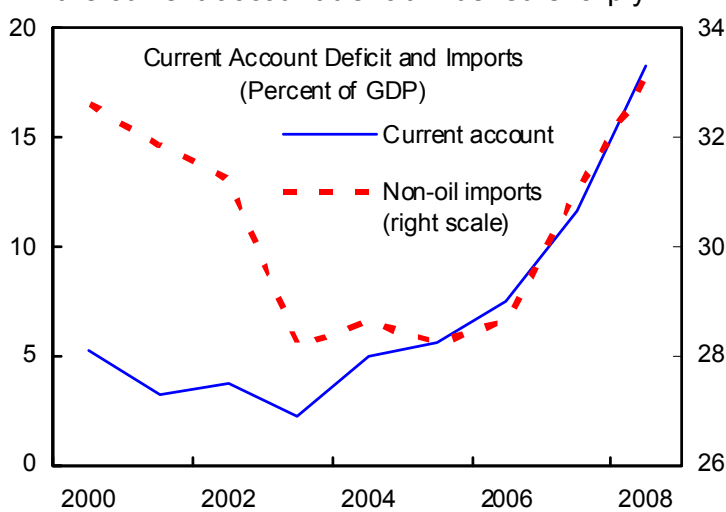

driven mostly by private consumption...

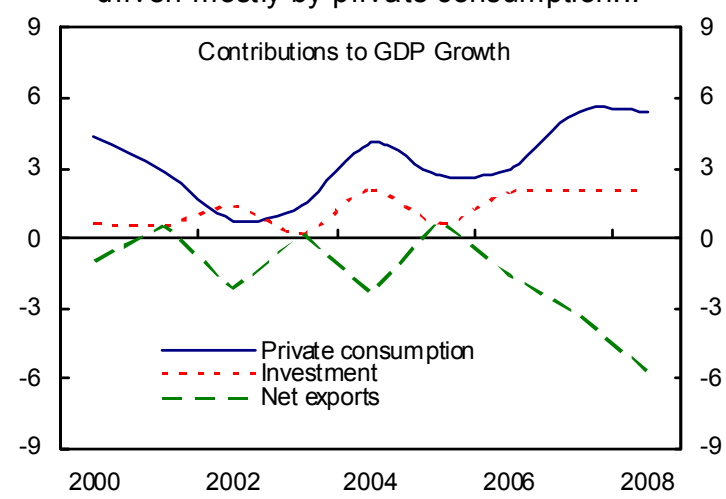

Prices of goods and assets accelerated,...

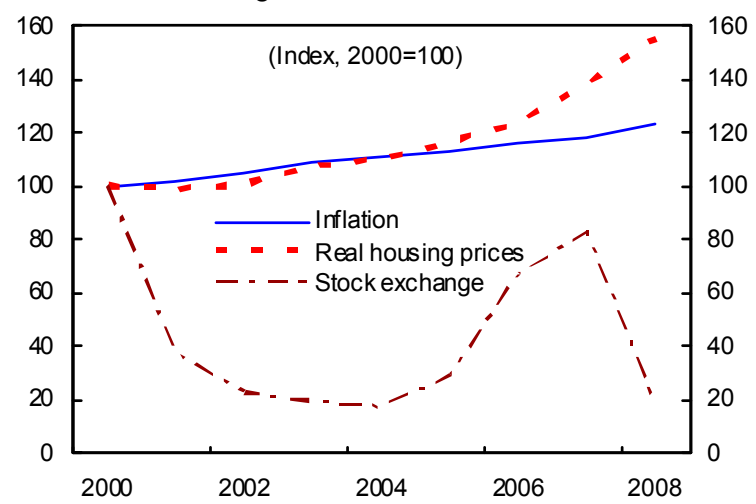

... and debt ratios worsened.

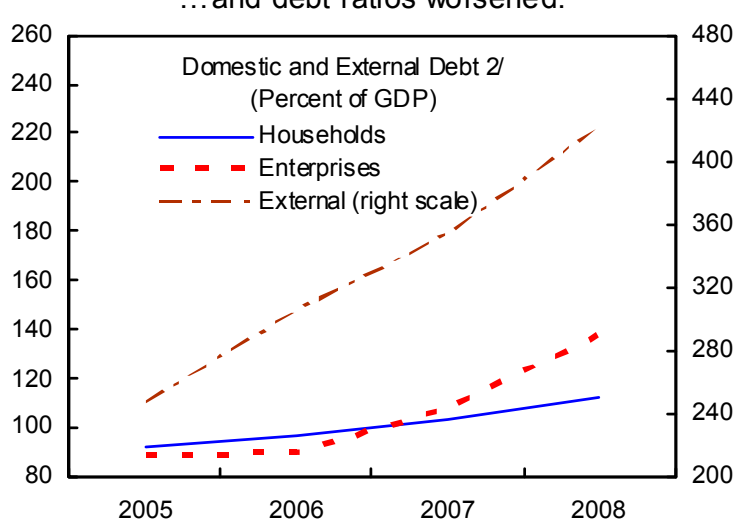

Sources: European Commission; National Statistical Service; and IMF staff calculations and projections.

$1 /$ Series breaks in 2002, 2005 and 2008 due to improving coverage.

2/ Household and enterprise debt comprises domestic debt. External debt is largely private sector bank debt and includes nonresident deposits in the banking sector. 
result, households and corporations are highly leveraged, property prices have risen sharply, and banks and households are exposed to the property market, although loan-to-value ratios of 70-80 percent should provide banks some buffer against property price declines.

\section{Double-digit and growing current account deficits indicate overheating and} competitiveness problems (Figure 3). The current account deficit widened sharply in 2007-08, although temporary and technical factors partly explain the large headline numbers of $2008\left(18 \frac{1}{2}\right.$ percent of GDP). ${ }^{4}$ While Cyprus has been gaining market share in financial services, it has been losing ground to low-cost competitors in the manufacturing and tourism sectors. An application of the CGER methodology shows Cyprus facing a significant competitive disadvantage. All estimates indicate the same directional conclusion, and are consistent with recent developments in wages and Cyprus: Estimation of Equilibrium Current Account Balance Using CGER 1/ (Percent of GDP) productivity in the manufacturing sector. The external position could be vulnerable if the current sources of financing-FDI and non-resident deposits into the banking system-were to decline. ${ }^{5}$

4. There was a sharp uptick in inflation in 2008 (Figure 4). Both demand-pull and cost-push factors contributed, such as a large and positive output gap, high oil and food prices, and wage increases indexed to past inflation. So did temporary factors such as a severe drought and euro adoption.

\section{The largely revenue-based fiscal consolidation started unwinding in 2008 (Figure} 5). Historically large budget deficits were converted into surpluses by 2007 , and public debt is a low 49 $\frac{1}{2}$ percent of GDP (mostly domestic and long-term). However, consolidation was largely revenue-based and, to some extent, dependent on temporary factors, such as a

\footnotetext{
${ }^{4}$ An estimated one-third of the headline current account deficit can be attributed to temporary and technical factors, e.g. drought-related water imports, higher reinvested profits (with an FDI counterpart in the financial account), and a one-time increase in car imports following the reduction in excise tax to EU levels ahead of euro entry.

${ }^{5}$ While private sector external debt remains high (421 percent of GDP, including non-resident deposits, about half of which is short-term), net external debt is small (4 percent of GDP), having declined sharply in 2008 as banks accumulated assets abroad.
} 
Figure 3. Cyprus: Competitiveness Indicators, 2000-08

Competitiveness remains a problem with a widening current account deficit.

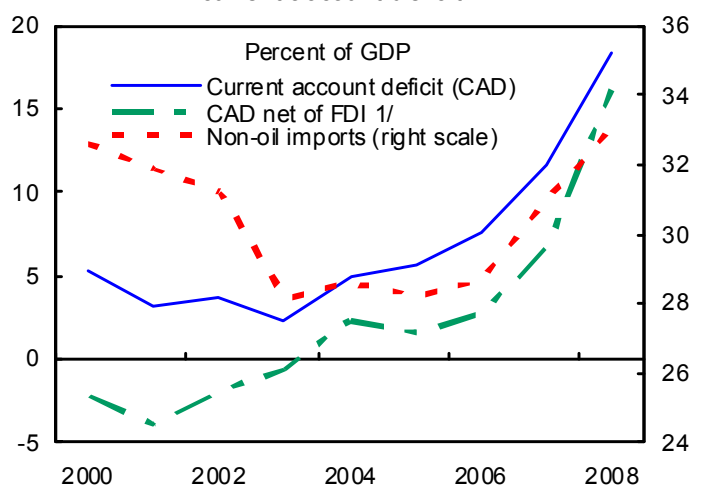

...appreciating real effective exchange rates...

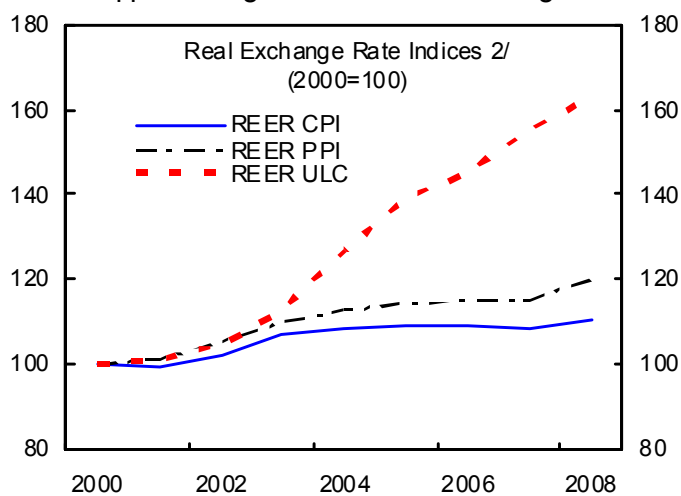

...and increas ing product ULC.

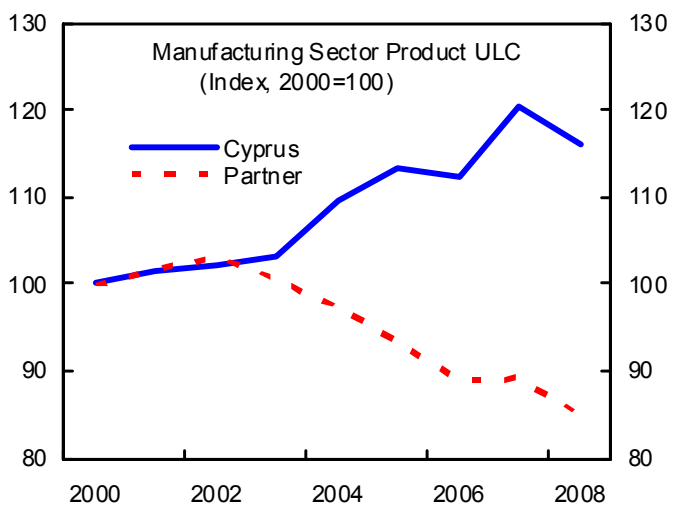

..stagnant goods and tourism market shares...

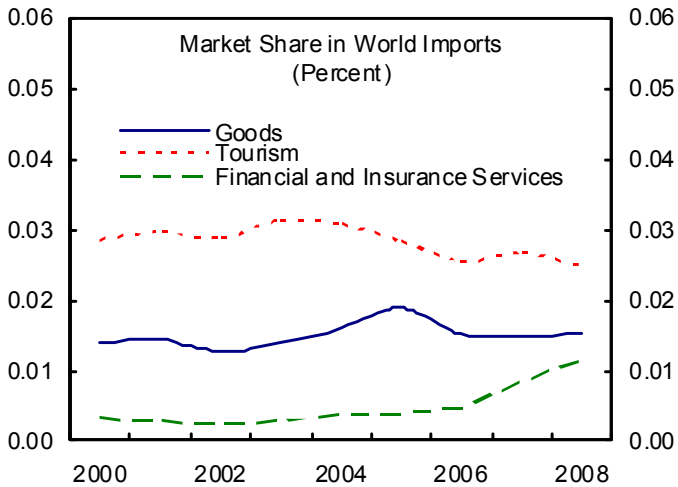

...declining productivity and profitability in the

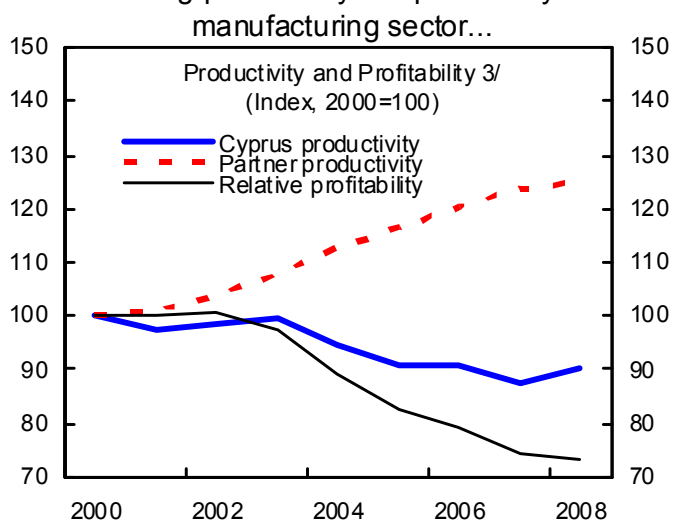

The current account deficit exceeds estimated equilibrium levels.

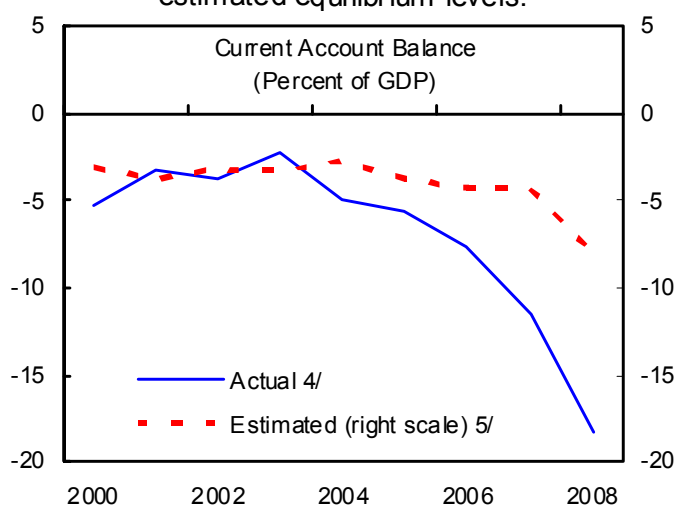

Sources: European Commission; National Statistic al Service; and IMF staff calculations and projections.

1/ Current account net of foreign direct investment and EU funds.

2/ Trade weights based on 2004-2006 data for exports and imports. Partners countries comprise the top trading partners: Belgium, China, France, Germany, Greece, Japan, Israel, Italy, Netherlands, Rus sia, Spain, UK, US.

3/ Relative profitability is defined as the producer price index divided by unit labor cost index of Cyprus relative to that of tradeweighted partners. The indices reflect developments in the manufacturing sector.

4/ A third of the deficit in 2008 is due to temporary and technical factors as described in footnote 5.

$5 /$ The equilibrium current account balance is computed from the equilibrium relationship between current account balance and a set of fundamentals projected to prevail in the medium term. The current account regression is estimated using a panel data set of 54 advanced and emerging market economies over 1973-2004. A set of fundamentals includes fiscal balance, demographics, net foreign assets, oil balance, economic growth, economic crises, financial center, and financial development. 
Figure 4. Cyprus: Price Indicators, 2000-08

(Year-on-year percent change, unless otherwise indicated)

An uptick in headline and core inflation in $2008 .$.

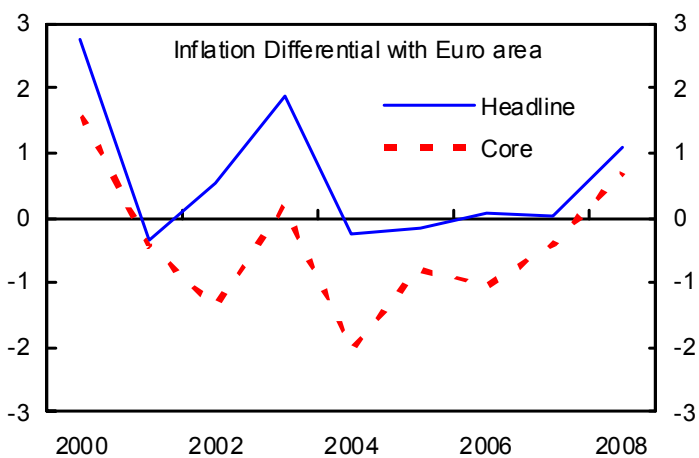

increases in world oil and food prices,...

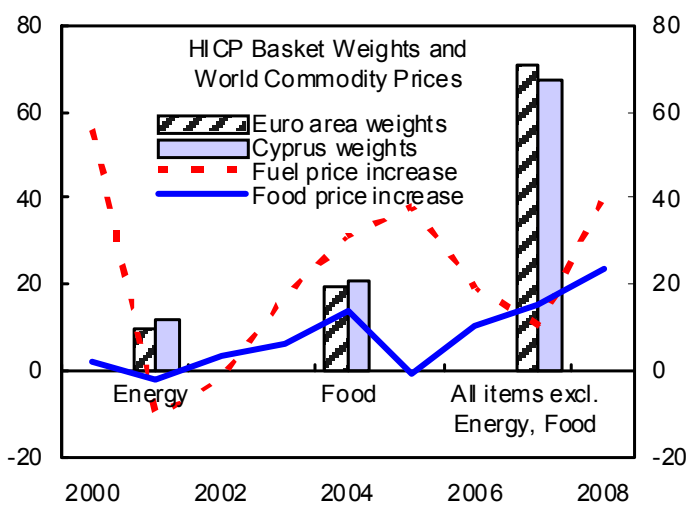

The 2008 inflation spike was due to lagged inflation effects, world price increases and one-off factors. 2/

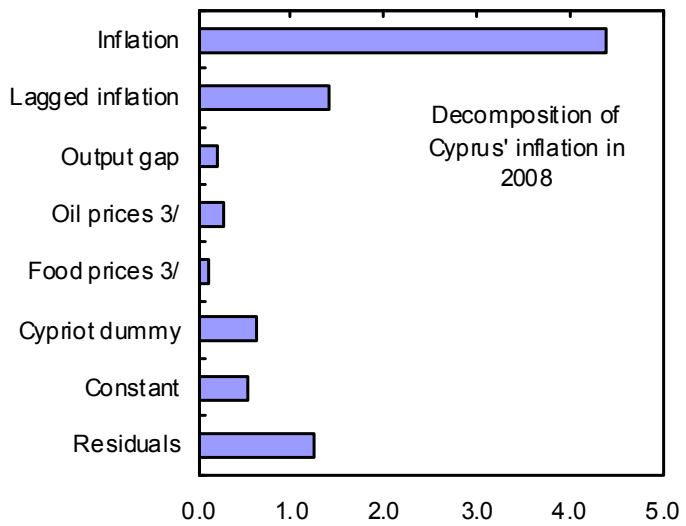

reflected a small euro changeover effect,...

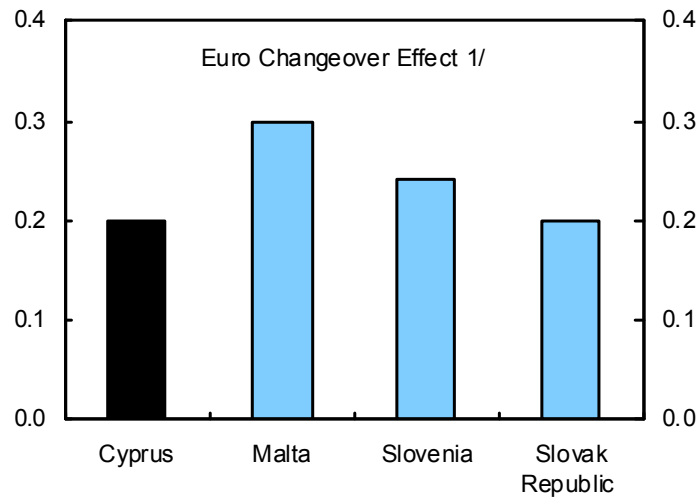

strong real wage growth, and a positive output gap.

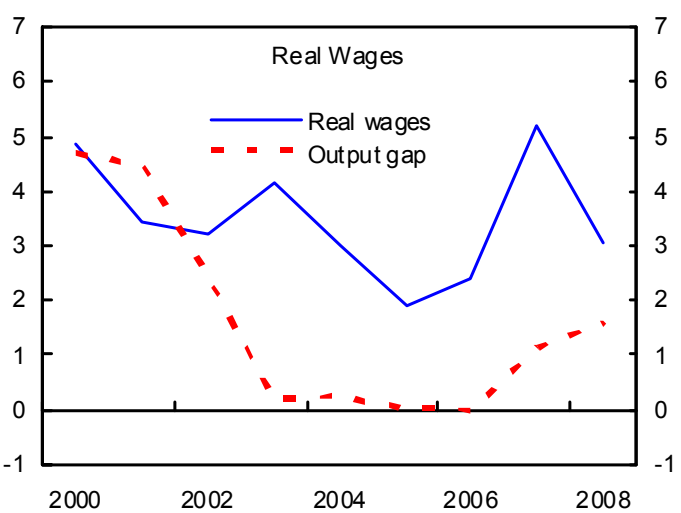

Country-specific temporary factors largely explained the inflation differential with the euro area. 2/

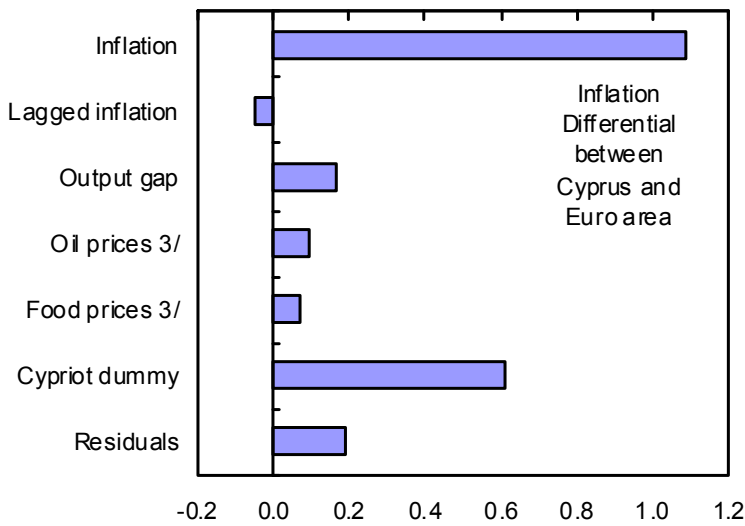

Sources: Euros tat; National Statistical Service; and IMF staff calc ulations.

1/ Cyprus adopted the euro on January 1, 2008. The estimates of the euro changeover effect were taken from the European Commission (http://ec.europa.eu/cyprus/news/cy_ma_euro_en.htm).

$2 /$ Augmented Phillips curve regression for 15 euro area countries (1997-2007): Inflation (t) $=0.5+0.7$ Inflation (t-1) +0.4 Output gap

$(t)+.004$ Oil price increase $(t)-.0006$ Food price increase $(t)+0.6$ Cyprus dummy $(t)+.09$ Cyprus ${ }^{\star}$ Oil price change $(t)+.07$ Cyprus*Food price change (t). One-off factors include: drought, euro changeover impact, and tax changes.

$3 /$ Change in world oil and food prices. 
Figure 5. Cyprus: Public Finances, 2004-08

(Percent of GDP, unless otherwise indicated)

Cyprus has reduced its budget deficit...

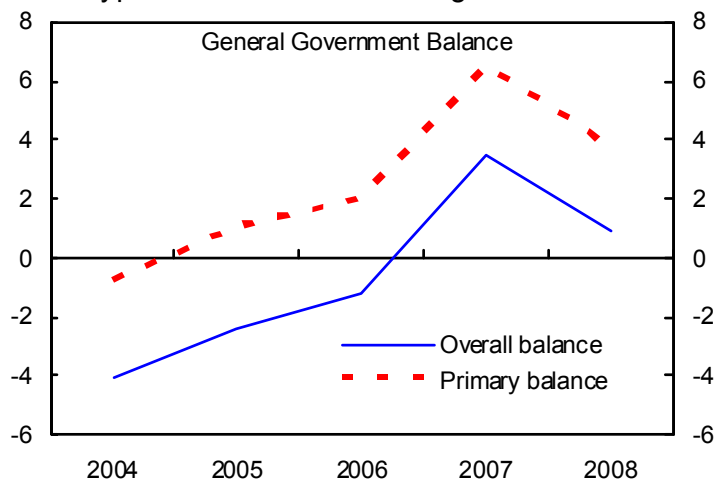

... as rising profits and real estate capital gains

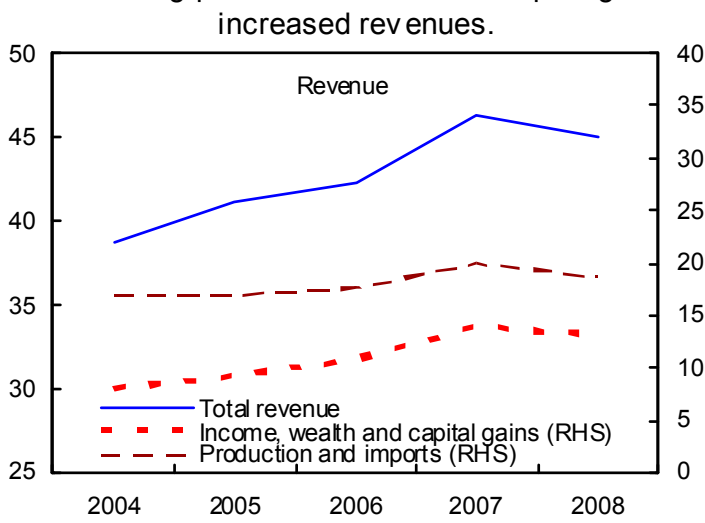

...have been increasing recently.

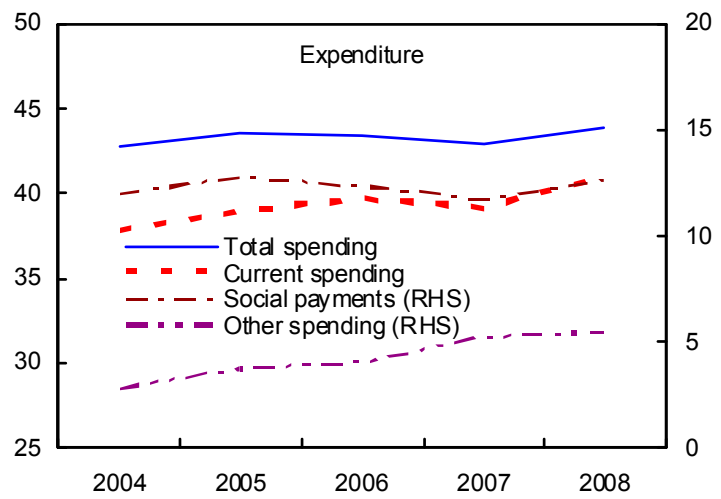

and public debt...

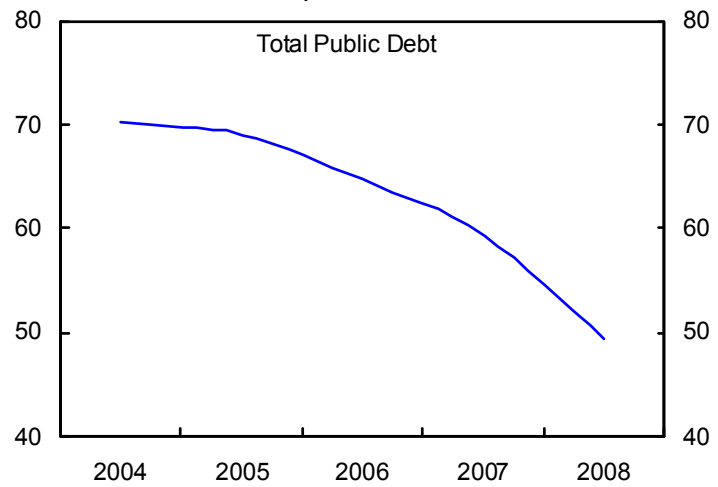

However expenditures, while not out of line

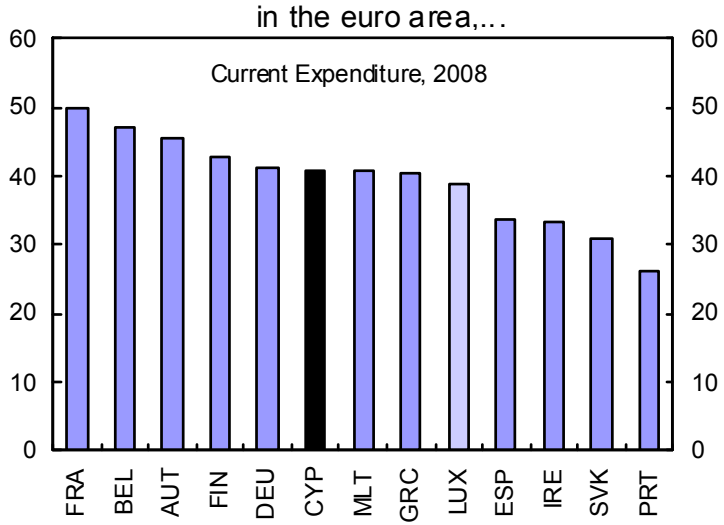

The budget wage bill has increased faster than the euro area average.

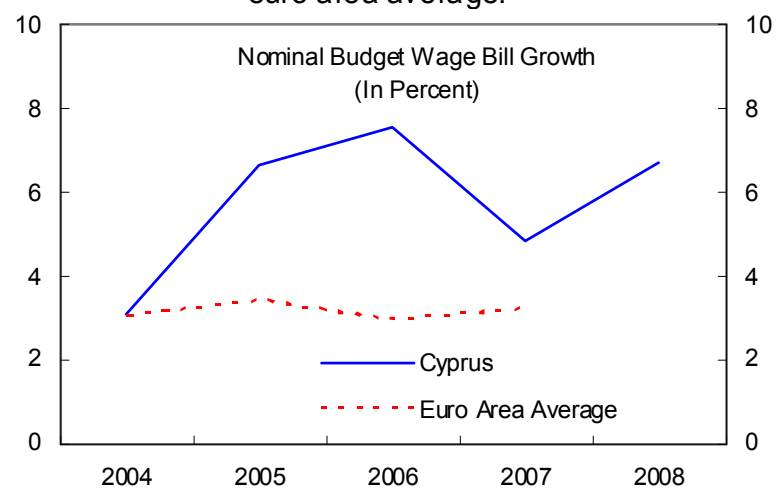

Sources: European Commission; Global Economic Forum, Global Competitiveness Report, 2008-09; Eurostat; Haver Analytics; and IMF staff calculations 
property price boom and a revaluation of assets. ${ }^{6}$ On the spending side, fundamental reforms did not materialize while social spending has grown. Besides savings on debt service, the government has exercised some control over wages, defense and capital expenditures, and slowed the increase in pension spending by gradually increasing the retirement age and tightening the pension eligibility criteria somewhat. The recently enacted pension reform places the burden of adjustment largely on contribution increases and does not address the large ageing-related increases in pension expenditures. In 2008, the budget surplus started unwinding due, in part, to the government's emphasis on untargeted social spending with the intention of supporting social cohesion. Despite continued growth in output, imports, and property prices, the 2008 general government budget surplus declined sharply to 0.9 percent of GDP.

\section{The financial sector is withstanding the global crisis; public recapitalization has}

not been necessary. Both resident and non-resident deposits have held steady thanks to confidence in the banking system, the planned expansion of deposit insurance, and the relative strength of the banking sector compared to that of the region. Banks reportedly do not face liquidity problems.

\section{Nevertheless, the banking sector poses risks by virtue of its size and} concentration (Table 2, Figure 6). ${ }^{7}$ With domestic assets of some 690 percent of GDP, the financial sector is large relative to the economy. Moreover it is concentrated, with the landscape dominated by three domestic banking groups - the Bank of Cyprus, Marfin Popular Bank, and Hellenic Bank - spanning banking, insurance, investment banking, and asset management subsidiaries. Problems in the banking sector can therefore quickly escalate to systemic proportions with serious economic repercussions. The big three have also diversified geographically by tapping emerging European economies. Foreign presence in the domestic market is growing and significant, with Greece's Alpha Bank the predominant foreign player. Banks have been competing aggressively with local cooperative banks - the second largest presence in the domestic financial sector-for market share, resulting in lower margins.

\section{Banks are taking steps to preserve profitability and ensure capital adequacy.}

They are restructuring balance sheets by increasing interest rate spreads to preserve profitability, strengthening capital by issuing subordinated or convertible loan capital, securing funding, and enhancing risk management. Lending has decelerated as underwriting standards have been tightened to protect asset quality. Deposit rates have started to decline as

\footnotetext{
${ }^{6}$ Public coffers also benefited from tax increases and a wider tax base due to harmonization with the EU; stronger profitability and imports; and increases in revenues from land and survey fees.

${ }^{7}$ Financial sector discussions are largely based on the conclusions of the September-October 2008 FSAP mission, also summarized in the accompanying Financial System Stability Assessment report (July 2009).
} 
Figure 6. Cyprus: Banking Sector

(Percent of GDP, unless otherwise noted)

Cyprus is a heavily ban ked economy...

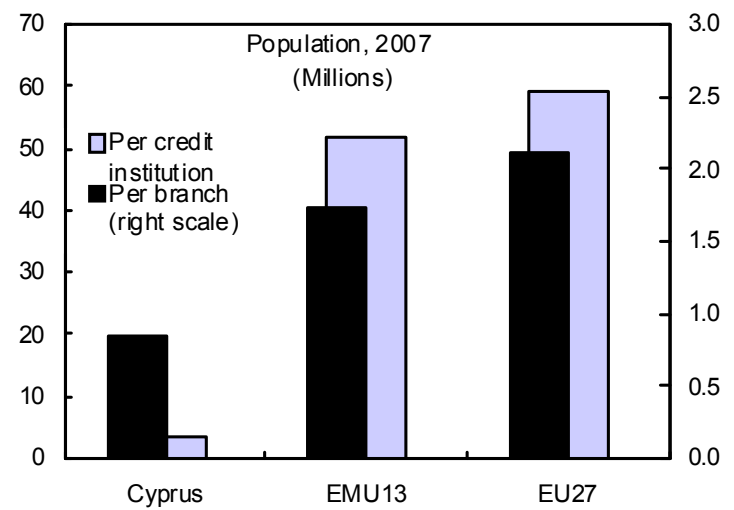

The financial sector is do minated by domestic banks...

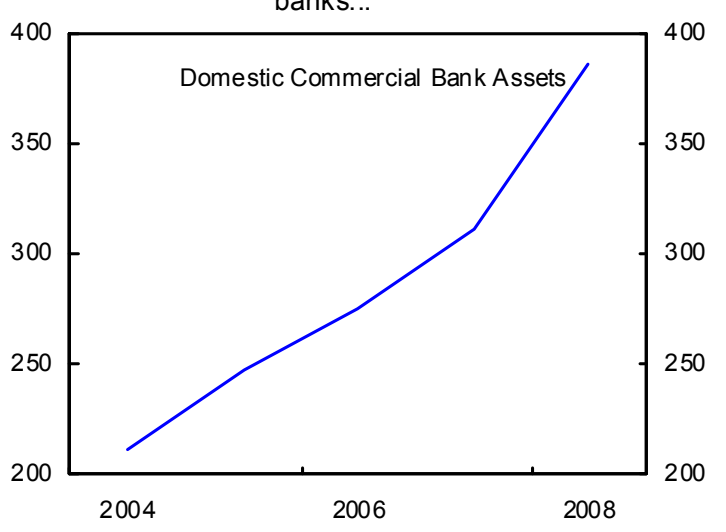

Foreign subsidiaries are growing and significant...

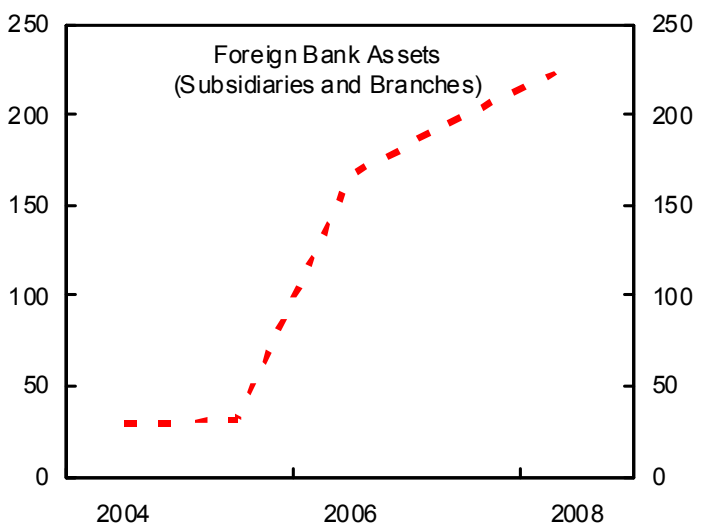

... with a large share of bank assets to GDP.

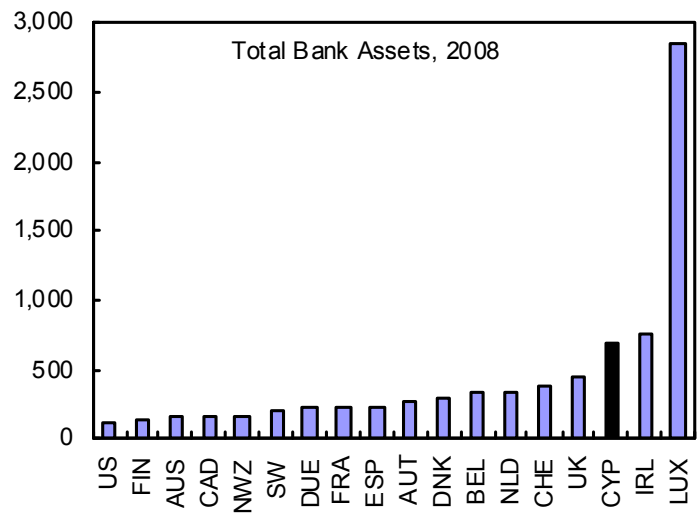

...particularly three large domestic banks.

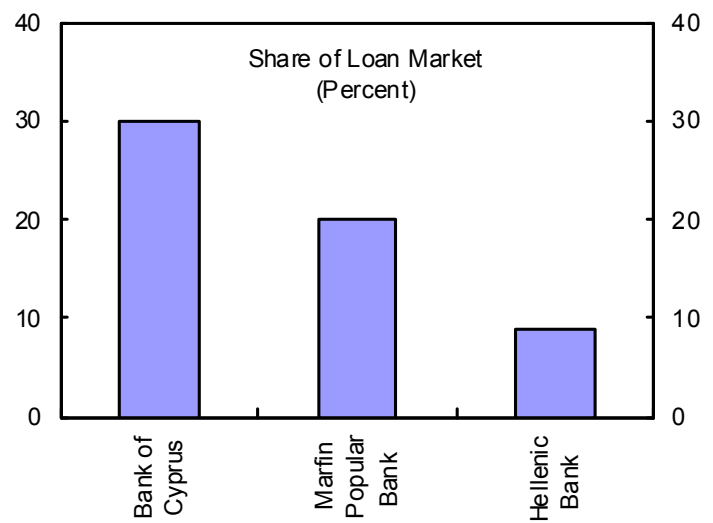

... and the two biggest domestic banks have large exposures abroad.

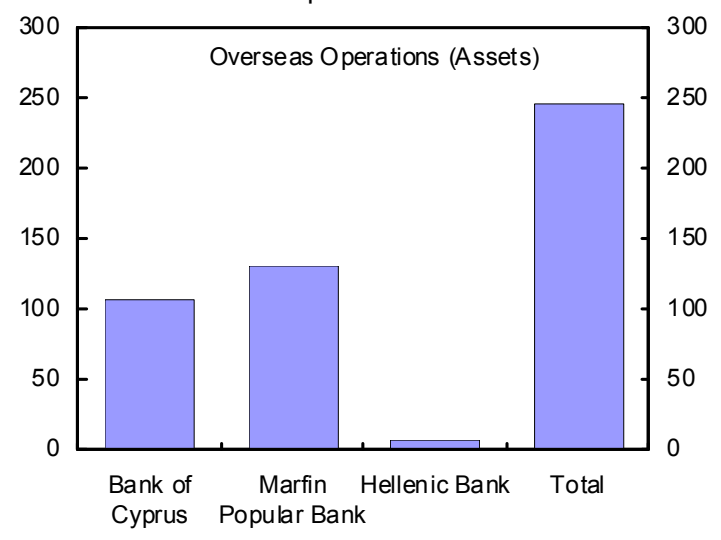

Sources: Central Bank of Cyprus; European Central Bank; Global Financial Stability Report, IMF; Financial Statements of Banks, Fitch, and Moody's. 
Figure 6 (contd.) Cyprus: Key Financial Sector Indicators 1/
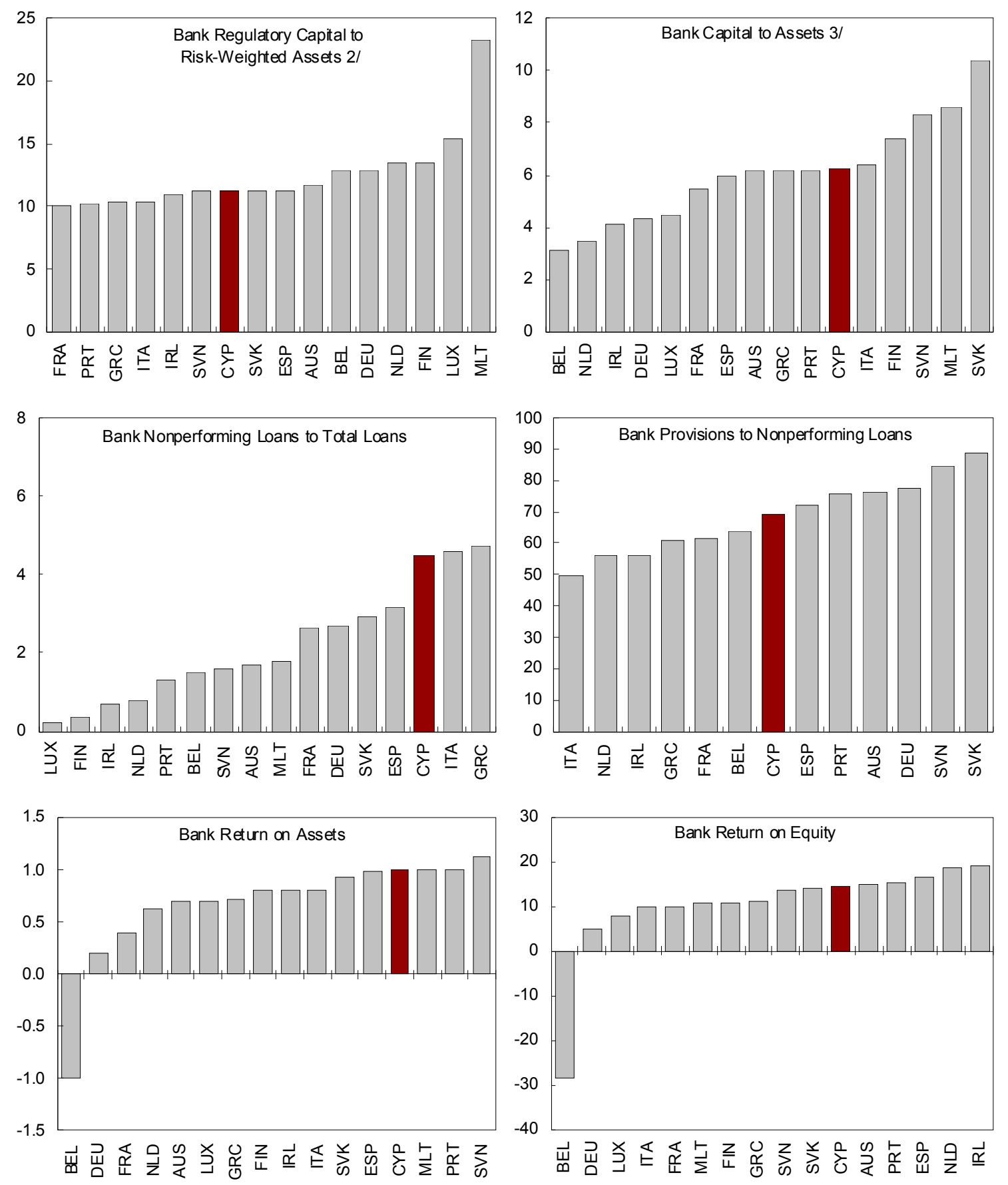

Source: Global Financial Stability Report, April 2009 and Central Bank of Cyprus.

1/ Data for individual countries are for different dates (statistical appendix tables 22-27 of the Global Financial Stability Report, April 2009). Data for Cyprus is for end-2008.

2/ Regulatory capital refers to the sum of Tier 1 and Tier 2 capital.

$3 /$ Cyprus data refers to the ratio of the capital employed to total assets. 
liquidity concerns have subsided. Overseas operations are under close scrutiny, and have been frozen in some cases as banks wait for the situation to improve.

9. The government and $\mathrm{CBC}$ have taken action to ensure the soundness of the banking system (Table 3 ). There has been significant progress in implementing EU Directives and recommendations made by the recent FSAP. In particular, deposit insurance coverage and funding is being increased; a crisis management law is being drafted to empower the government to preemptively address liquidity or insolvency problems affecting financial institutions; and a legal and regulatory framework for covered bonds has been initiated to increase the available collateral for banks to use in order to fully reap the benefits of the refinancing flexibility offered under the ECB's facilities.

10. However, bank soundness indicators have deteriorated and are likely to weaken further as the downturn progresses (Table 4). Bank profitability has declined due to low interest margins induced by intense competition, mark-to-market losses on assets, and larger provision write-offs. NPLs, while low, have risen in all sectors. Capital buffers have declined.

\section{Reunification remains elusive, although discussions are continuing at the} technical level. Full-fledged settlement negotiations to resolve the decades-long division of Cyprus got under way in September 2008 as a solution was favored by all concerned parties. However, progress has been slow and the two sides remain a long way from agreeing on the major issues that need to be tackled.

\section{ECONOMIC OUTLOOK: TEPID AND UNCERTAIN}

\section{As a small open economy on the outskirts of Europe, Cyprus is unlikely to} remain shielded from the global crisis. Two of its most important economic activitiesconstruction and financial services - are feeling the pinch, while tourism and exports have been struggling against low cost competitors for several years. Its most important economic partners - the U.K., Greece, Russia - are facing economic difficulties of their own.

13. All agreed that growth is headed for a sharp decline in 2009-10 (Table 5-6). However, growth is expected to exceed that of the euro area because of the relative resilience of the financial sector, the absence of a credit crunch, and large real wage increases. However, at one percent, the government's forecast is more optimistic than staff's as they expect private consumption to moderate more gradually and fiscal policy to support growth. Staff's central estimates are for a more pessimistic $1 / 3$ percent growth in 2009 , a key difference being the assumption that highly leveraged households and corporations will increase precautionary
Cyprus: Growth Forecasts for 2009-10

\begin{tabular}{lrrr}
\hline & 2008 & 2009 & 2010 \\
\hline Growth & & & \\
IMF & 3.6 & 0.3 & 1.1 \\
Ministry of Finance & 3.6 & $0.5-1.0$ & $0.5-1.0$ \\
Central Bank of Cyprus & 3.6 & 0.4 & 0.7 \\
European Commission & 3.6 & 0.3 & 0.7
\end{tabular}

Potential Growth

$\begin{array}{llll}\text { IMF } & 3.2 & 2.2 & 2.4\end{array}$

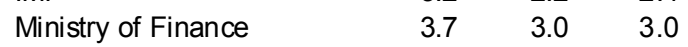

$\begin{array}{llll}\text { Central Bank of Cyprus } & 3.7 & 2.8 & 2.1\end{array}$

$\begin{array}{llll}\text { European Commission } & 3.4 & 2.1 & 2.4\end{array}$


savings in the short-term to rebuild balance sheets as home prices, profitability, and employment opportunities decline. ${ }^{8}$ This will be reinforced by a moderation of credit as banks restructure their own balance sheets. In addition, given high import elasticities, the fiscal stimulus is assumed to have a smaller net impact on growth. With rising savings and investments delayed until opportune times, the current account deficit is expected to improve sharply, helped also by lower commodity prices.

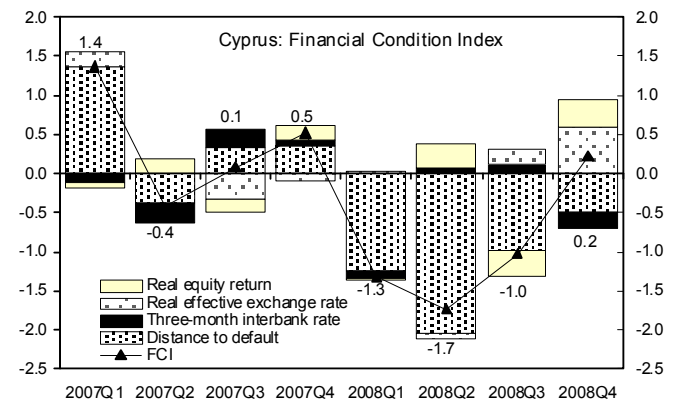

Source: IMF staff estimates.

Note: The Financial Conditions Index ( $F \mathrm{Cl})$ accounts for the endogenous response of financial

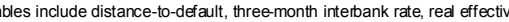
exchange rate, and real equity return. Data are from 1995:Q1-2008:Q4.
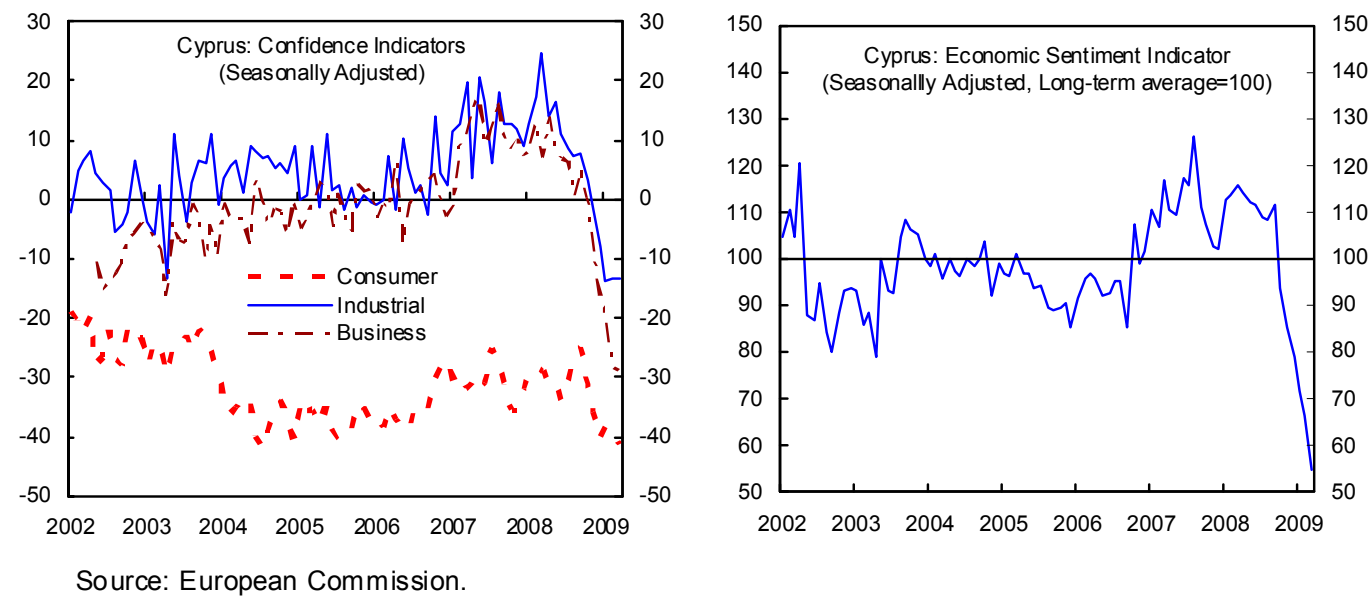

14. Growth forecasts are subject to uncertainty; a worse outcome cannot be ruled

out. The international macroeconomic and financial environment is still in flux. Moreover, the financial sector - a key driver of growth — is vulnerable, and partly reliant on non-resident funds. These inflows, while so far steady, could deteriorate or strengthen, depending on the growth outlook in originating countries, and the relative state of their banking sectors. Finally, while some correction in property prices is envisaged and is already underway as foreign investments in vacation homes have stalled, data constraints make it difficult to gauge the amount of adjustment in the pipeline. ${ }^{9}$

\section{Medium-term recovery will likely be tepid, hindered by impaired}

competitiveness. Absent significant improvements in competitiveness, growth is forecast to recover in line with partner country growth to settle at about a moderate 3 percent per year, compared to recent growth rates of $4-4 \frac{1}{2}$ percent. Private domestic demand will continue to

\footnotetext{
${ }^{8}$ Households are vulnerable to interest rate increases given the large share of adjustable-rate mortgages.

${ }^{9}$ House prices are expected to decline by some 15-20 percent on average, with larger declines in the vacation home market. Prices are expected to adjust gradually due to a lengthy foreclosure process and structural rigidities delaying property-related transactions.
} 
be the main driver, although unlikely to revert to the levels of 2007-08 on the assumption that the over-expansion in the housing and credit markets will not return. Net exports would provide a drag as export market shares stay stagnant while imports recover. As the savings-investment balance deteriorates, the current account deficit will stay large. The external position, therefore, still looks vulnerable, especially if the assumed recovery in non-resident deposit inflows in line with partner country growth is not forthcoming. Growth is expected to be below potential, even as potential output drops in the near-term due to lower capital accumulation and capacity utilization and a reduction in the workforce especially in the worst-hit tourism and construction sectors which rely on immigrant labor. Over the medium term potential output growth is expected to decline moderately mainly because of an ageing population which will only partially be compensated by immigration.
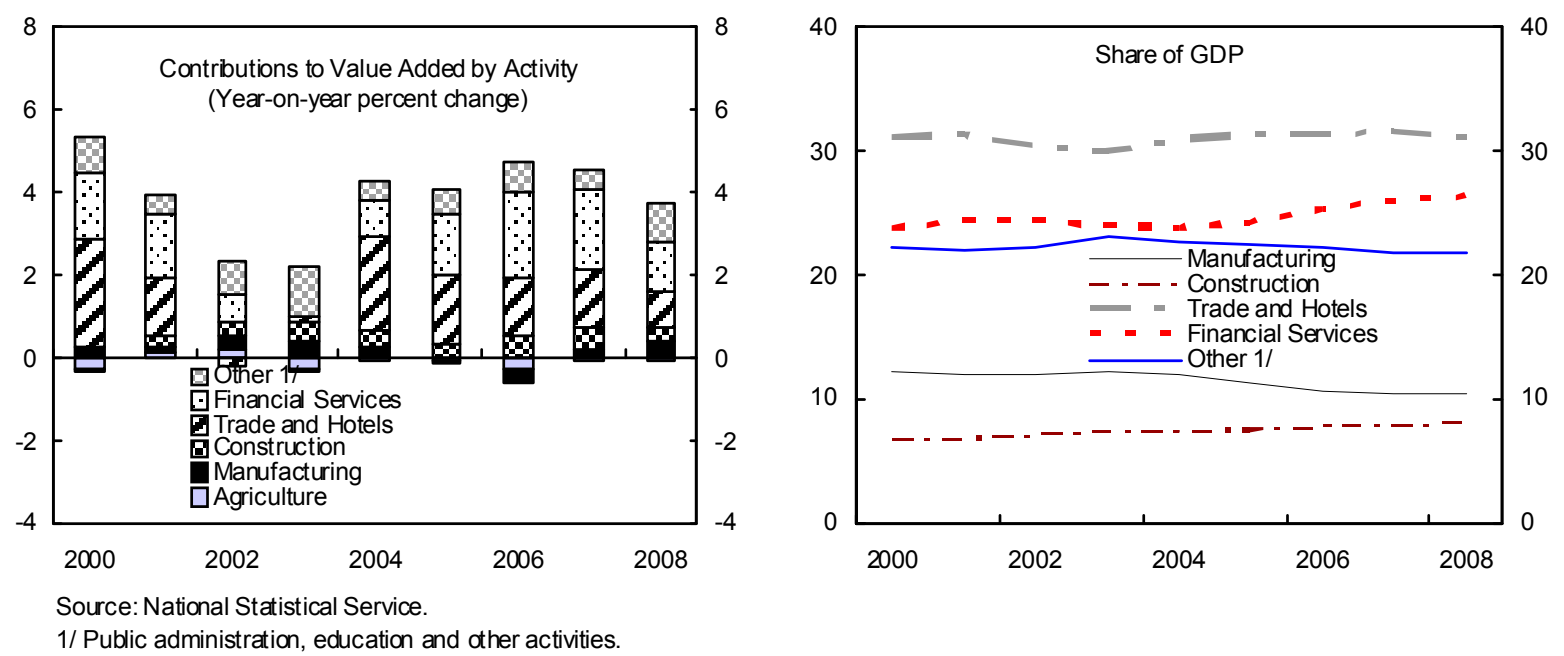

1/ Public administration, education and other activities.

\section{POLICY DISCUSSIONS}

16. Discussions focused on policies to manage short-term risks without endangering medium-term sustainability. The onus is on fiscal policy, financial sector supervision and structural reforms to deliver the authorities' medium-term objectives of promoting growth and fostering social cohesion.

\section{A. Public Finances: Living Within Means}

17. Staff supported the government's fiscal objectives and priorities. According to the Stability Program, the government intends to keep the budget deficit below 3 percent of GDP in 2009-10 and balance the budget over the medium term. ${ }^{10}$ Moreover, it intends to curtail public consumption while emphasizing productivity-enhancing investments (mainly infrastructure), structural reforms and social spending. For a small open economy like Cyprus, given high import elasticities, fiscal expansion is likely to be less effective in supporting growth. As markets increasingly differentiate between country risks even within

\footnotetext{
${ }^{10}$ Stability Program, February 2009.
} 
the euro area, the fiscal multiplier could turn negative if large deficits reduce investor confidence in fiscal sustainability. A conservative fiscal stance would, on the other hand, help sustain confidence in the financial sector by improving the perceived ability of public finances to absorb financial sector-related contingent liabilities, and keep public sector guarantees credible. In particular, a spending-based consolidation is appropriate as it would be more durable, given international experience. Moreover, although calls for discretionary tax cuts should be resisted, all agreed that higher tax rates could hurt competitiveness and impact foreign capital inflows thereby endangering external viability.

\section{Views differed on the expected fiscal outcome for 2009-10 and, therefore, the} need for corrective policies

(Table 7). Staff estimates

indicate that, on current

policies, public finances are

likely to enter an unsustainable

debt-deficit cycle. The

measures identified so far are

all on the revenue side, with relatively small and temporary effects on the budget deficit which will not compensate for revenues lost due to the permanent housing market correction and softening growth. On the spending side, although the stimulus package is in line with the European Economic Recovery Plan ${ }^{11}$, staff expressed concern that other spending plans have been neither timely, temporary, nor targeted. Envisaged hiring plans and wage increases will permanently increase the largest component of budget spending-
Cyprus: General Government Budget Estimates, 2009-10 (Percent of GDP)

\begin{tabular}{lrrrrrr}
\hline & \multicolumn{2}{c}{2009} & & \multicolumn{2}{c}{2010} \\
\cline { 2 - 3 } \cline { 5 - 6 } & Authorities & IMF & & Authorities & IMF \\
\hline Total revenue & 43.0 & 42.6 & & 42.9 & 42.6 \\
$\quad$ Taxes on income, wealth, property & 12.0 & 11.8 & & 12.1 & 11.9 \\
$\quad$ Social contribution & 9.1 & 9.2 & & 9.4 & 9.7 \\
Total expenditure & 45.9 & 46.5 & & 47.2 & 48.5 \\
Overall balance & -2.9 & -3.9 & & -4.2 & -5.9 \\
Primary balance & -0.5 & -1.5 & & -2.0 & -3.6 \\
\hline
\end{tabular}

Source: Ministry of Finance, Cyprus. Revised estimates as of June 2009.
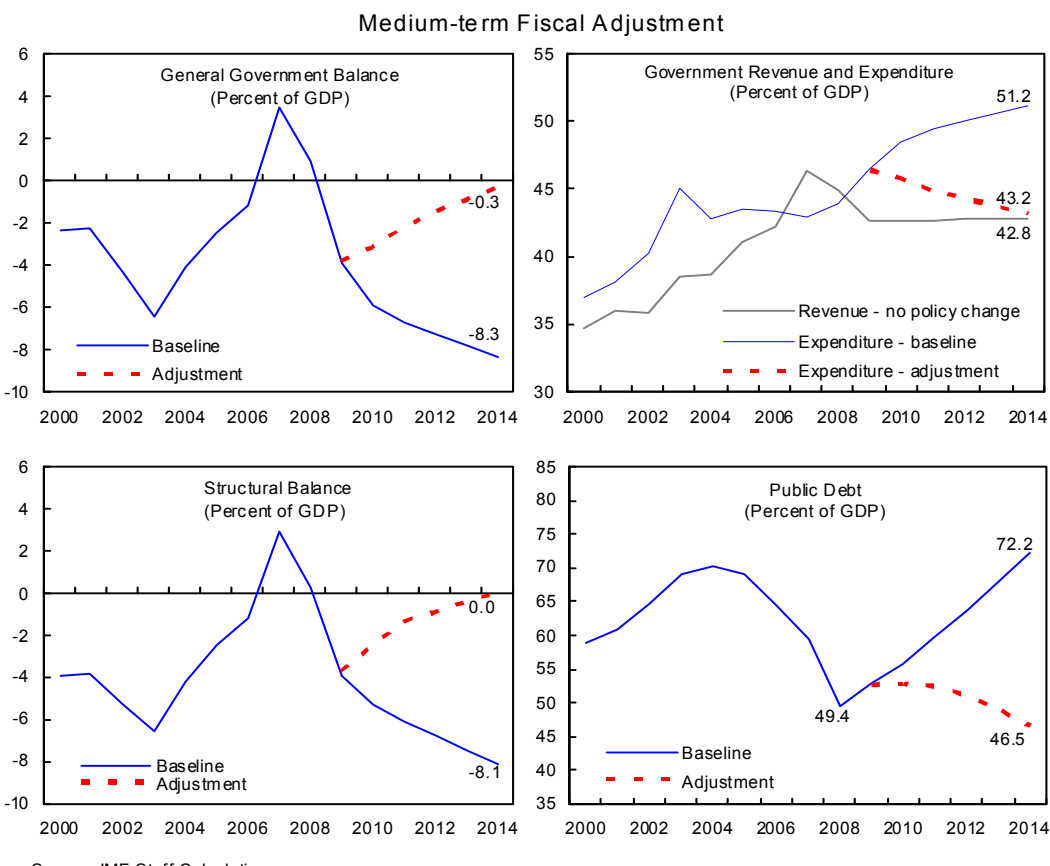

payroll—significantly starting

in 2010, productivity-enhancing investments have been slow to get off the ground, plans to expedite private investment approvals have not been effective, and the large increases in

\footnotetext{
${ }^{11}$ Fiscal stimulus measures (amounting to $1 \frac{1}{2}$ percent of GDP) were announced in late 2008 and will be implemented in 2009-10. They include temporary tax relief measures for tourism and housing loan subsidies to support construction.
} 
social support measures introduced in past years have not been targeted. Reflecting these pressures and rising ageing-related costs, the general government deficit is estimated to reach some 4 percent of GDP in 2009, a sharp reversal from the surpluses of 2007-08, and expand thereafter. The government's own estimates indicate a similar trajectory but better outcomes largely because of more optimistic assumptions about the economic outlook.

\section{Staff indicated that policies would need to be strengthened to achieve the} government's own objectives. Specifically, the budget deficit would need to be tightened by an estimated $1 / 2-3 / 4$ percent of GDP a year on average compared to the baseline, with a significant upfront course correction in 2009-10. The reduction of the wage bill - a third of total spending - should be a key priority, although staff acknowledged that this could be met with stiff resistance from the unions. This would require hiring and wage controls and a more efficient use of civil servants in the context of a broader public administration reform. ${ }^{12}$ It may also be time to extend the concept of flexicurity from the private sector to the public sector. ${ }^{13}$ These measures would control the wage bill, reduce the crowding out of the private sector in the labor market, improve social cohesion, and increase productivity. To further enhance social cohesion and protect the budget, social support measures should be targeted to reach the truly needy, a proposal the government was willing to consider. However, it is not clear whether it intends to revisit the untargeted schemes that were introduced in the past, also recommended by staff. Finally, staff emphasized that it would be critical that the temporary stimulus measures be reversed when the economy recovers and that a mediumterm budget framework be introduced in line with the 2006-07 IMF technical assistance. ${ }^{14}$

\section{The government's intention to support fiscal policy through improved public} sector asset-liability and cash management is welcome. However, staff noted that an assessment of total budget liabilities would need to be bolstered by transparently accounting for contingent liabilities. These would need to be monitored carefully so that overall exposures do not deteriorate rapidly as economic conditions worsen. In addition, public sector aid programs (such as the loan guarantee scheme to SMEs) should be designed to protect competition and minimize moral hazard (by offering partial guarantees) and adverse selection (limiting guarantees to new lending and to sectors where creditor quality is easily verifiable).

\footnotetext{
${ }^{12}$ For example, the Public Services Law of 1990 prohibits the redeployment of civil servants across the public sector.

${ }^{13}$ Flexicurity refers to the introduction of flexible but reliable employment contracts in the labor market (National Reform Programme, October 2008).

14 The recommendations include, inter alia, changes in the legal framework, institutional coverage, forecasting and presentation, and the modernization of personnel management.
} 
21. The passage of long-delayed pension reforms is commendable; however, staff indicated that additional reforms may be needed down the road to curb ageing-related spending. The recent reforms increase contribution rates, tighten eligibility criteria, and aim to establish an independent body to manage assets. Real reserves are being accumulated in the Social Investment Fund

\begin{tabular}{lrrrr}
\multicolumn{1}{c}{$\begin{array}{c}\text { Cyprus: Pension Reform } \\
\text { (Percent of GDP) }\end{array}$} & & & \\
\hline & 2007 & 2020 & 2030 & 2060 \\
\hline Pension expenditure (before reform) & 6.8 & 8.9 & 10.8 & 17.1 \\
Pension expenditure (after reform) & 6.8 & 8.4 & 10.0 & 16.0 \\
Contributions (before reform) & 4.2 & 4.3 & 4.4 & 4.6 \\
Contributions (after reform) & 4.2 & 5.5 & 6.4 & 7.6 \\
Total age-related budget expenditures (before reform) & 42.9 & 45.2 & 46.9 & 61.7 \\
Total age-related budget expenditures (after reform) & 42.9 & 44.7 & 46.1 & 51.9 \\
Social Security Fund assets (before reform) & 36.8 & 30.9 & 9.9 & -182.1 \\
Social Security Fund assets (after reform) & 36.8 & 45 & 51.1 & 33.4 \\
\hline Source: National Authorities. & & & &
\end{tabular}
with periodic reviews to assess the Fund's viability and take necessary corrective actions. However, although reforms address long-term fiscal sustainability concerns through 2050 , by relying solely on contribution increases, they are disproportionately burdensome to workers and competitiveness. ${ }^{15}$ Staff believed that additional reforms will become necessary over time, including raising the retirement age in line with other euro area countries, indexing benefits to prices to reduce spending pressures, and better aligning public and private pension benefits (including by reducing lump sum payments to the former).

\section{B. Financial Sector: Prevention Is Easier Than a Cure}

22. Given the systemic importance of the large banking sector, there was agreement that policies must focus on nipping problems in the bud. Moreover, given the important contribution of the financial sector to growth, its resilience would serve as a bulwark against a greater deterioration of growth and - via reputational effects - enhance the growth potential of Cyprus. Furthermore, weaknesses in the financial sector could lead to outflows in non-resident deposits thereby undermining external sustainability. Therefore, early detection of risks and intervention will be key to preserving financial sector stability.

\section{Stress tests indicate that the most important risk to financial stability is the} worsening macroeconomic environment. This will likely affect asset quality, revenues and profitability, since the private sector is highly leveraged, and banks' credit portfolio remains relatively untested by an economic slowdown. While the pre-shock total capital adequacy ratio (CAR), including Tier 1 and Tier 2 capital, remains above the regulatory minimum, stress tests based on end-2008 balance sheets indicate that the banking system's large exposure to real estate and credit risk poses risks. Under extreme assumptions, losses at the four largest banks could increase by about $€ 3 \frac{1}{2}$ billion ( 20 percent of GDP), reducing the CAR from about $10 \frac{1}{2}$ percent to some $4 \frac{1}{2}$ percent. This would imply that capital injections of some $10^{1 / 2}$ percent of GDP would be needed to satisfy the minimum CAR of 8 percent.

\footnotetext{
${ }^{15}$ Catalan, Mario, Jaime Guajardo, and Alexander W. Hoffmaister, "Pension Reform: Addressing the Consequences of Aging," Selected Issues Papers, Country Report No. 07/71, 2007

(http://www.imf.org/external/pubs/cat/longres.cfm?sk=21895.0).
} 
Cyprus: Stress Tests on Four Largest Banks

(Percent, unless otherwise noted)

\begin{tabular}{lrrrrr}
\hline & \multirow{2}{*}{ Aggregated } & \multicolumn{3}{c}{ Individual Bank Level } \\
\cline { 3 - 6 } & & Mean & Maximum & Minimum & Median \\
\hline Pre shock CAR & 10.7 & 10.9 & 11.3 & 10.1 & 11.0 \\
Post shock CAR 1/ & 4.7 & 5.0 & 6.3 & 4.3 & 4.8 \\
Capital injection required to restore minimum CAR of 8 percent 2/ & 10.6 & 2.7 & 5.2 & 0.4 & 2.5 \\
\hline
\end{tabular}

Source: Central Bank of Cyprus and IMF Staff Calculations.

1/ Scenario assumptions: (1) NPLs up by 100 percent, LGD at 80 percent; (2) All interest rates down by 200 bps; (3) Exchange rate appreciation by 30 percent; (4) Real estate prices decline by 30 percent; (5) Equity prices decline by 50 percent.

2/ Percent of GDP.

\section{Risks from counterparty exposure and contagion exist, but have eased in line} with improving global financial conditions. Contagion from Greek parent banks is possible but unlikely since home country policies to limit systemic risk target financial groups as a whole, thereby reducing cross-border vulnerabilities. ${ }^{16}$ Likewise, Cypriot banks' operations in Greece and Eastern Europe expose asset quality to a slowdown abroad. ${ }^{17}$ As net lenders in the European money market, Cypriot banks have sizeable exposures to European financial institutions through bond investments, which exposes them to counterparty risk, although these have eased somewhat as governments and central banks have intervened to support banking systems in other countries. ${ }^{18,19}$

\section{Bank exposures related to interest rate, equity prices, foreign exchange and}

liquidity are controlled. Exposures to equity prices were reduced after the stock market collapse in 2001; bank equity investments stood at $1 / 4$ percent of total assets at end-April 2009. Direct exposure to foreign exchange risk is limited and extensively hedged ${ }^{20}$; banks' total net foreign currency open position amounted to about 1.2 percent of total capital at end-April 2009. Interest rate risk is hedged, with profits rising with interest rates as bank assets

\begin{tabular}{llr}
\multicolumn{2}{c}{ Cyprus: Liquidity Requirement } \\
\hline \multicolumn{2}{c}{ Liquidity } & \\
\hline Sight to 7 days & Max & -10 \\
Sight to 1 month & Max & -25 \\
Stock liquidity & Min & 20 \\
Foreign currency liability & Min & 70 \\
Foreign currency deposits & Min & 90 \\
Other foreign currency liability due within one year & Min & 10 \\
Other Foreign currency liability due after one year & & \\
\hline
\end{tabular}

Source: Central Bank of Cyprus.

\footnotetext{
${ }^{16}$ Recently, these banks have been downgraded or put on a negative watch by at least one of the three main rating agencies.

${ }^{17}$ In March 2009, Cypriot banks' total loan exposures relating to operations in Greece and Eastern Europe amounted to $32 \frac{1}{2}$ and 4 percent of total consolidated banking system exposure respectively.

${ }^{18}$ In December 2008, banks held $81 / 4$ and 103/4 percent of total consolidated assets in the form of placements and bonds issued by other Euro area banks and non-Euro area banks respectively.

${ }^{19}$ Kommunalkredit International Bank Ltd, a Cypriot subsidiary of Austrian Kommunalcredit AG, ceased operations after large losses in its derivatives portfolio.

${ }^{20}$ Banks are required to limit foreign currency open positions to 6 percent of capital.
} 
reprice more quickly than liabilities. Liquidity buffers are also reasonably high, thanks to conservative liquidity requirements.

\section{Going forward, there will be a need for continued vigilant supervision and} enhanced cross-border cooperation. Notwithstanding pressure on banks and supervisors to facilitate credit, it was recognized that Cyprus' reputation as a financial center depends on effective and arms length supervision by an independent and accountable central bank. Since liquidity of even relatively safe assets can suddenly evaporate at times of stress, and deposits - including non-resident and foreign currency deposits - remain more volatile than during normal times, staff indicated that the $\mathrm{CBC}$ will need to maintain its prudential regulation on liquidity requirements, implement the CEBS's guidance on liquidity management, and closely monitor developments in banks' funding, cross-border exposures, and counterparty risk management. Although the authorities wondered whether this was the right time to tighten capital requirements, staff indicated that the $\mathrm{CBC}$ could consider requiring banks to hold more capital - thereby forcing them to suspend dividend payouts and bolster capital - given the expected deterioration in asset quality and liquidity risk in the pipeline. Staff also advised that loan-to-value ratios on second homes may need to be reviewed in line with property price developments, and that the foreclosure procedure would need to be shortened to allow for a more rapid property price correction and bank balance sheet adjustment. All agreed that participation - as host and home supervisor-in supervisory colleges being set up for the largest EU banks by end-2009 should help strengthen cross-border supervision. Ongoing work in the EU to strengthen the crisis management framework (including deposit guarantee funding) is expected to strengthen the Cypriot authorities' preparedness further. Finally, staff indicated that, as in other jurisdictions with large financial systems, the supervisor should consider how to avoid the moral hazard effects associated with institutions that are "too big to fail".

\section{The FSAP recommendations to further improve supervision and the safety net}

were well received. The stress testing framework should be expanded to include a wider coverage of institutions (including the cooperatives) and risks. Better monitoring and cross-checking of results would help risk assessment, as would improved statistics on real estate and household leverage produced by the Statistical Services of Cyprus (CYSTAT). Additional resources would be required for supervision and financial stability assessments. Over the medium term, a single supervisor for all credit institutions operating in Cyprus could enhance efficiency, and establish a level playing field. Given the integrated nature of the financial sector in Cyprus, a more integrated supervisory structure based in the CBC would be preferable to the current sectoral approach.

\section{Structural Reforms: Translating Plans Into Action}

\section{There is widespread consensus that improving competitiveness will be key to} assisting recovery and enhancing growth potential. The authorities indicated that Cyprus remains attractive to foreign investors due to strategic, historical, institutional and economic advantages: a relatively low-tax regime, proximity to middle-eastern markets, regulatory 
reliability underwritten by the EU and increasing integration with the EU. The economy is being diversified into new businesses such as shipping, financial services, legal and accounting services, and repetitive tourism (through the purchases of vacation homes by foreigners). It is also gaining competitiveness in the non-tourism service sector. However, staff noted that Cyprus' global ranking on competitiveness indicators is low (Figure 7), reflecting the small size of the economy, high labor costs relative to Eastern Europe, competitiveness problems in the manufacturing and tourism sectors and a wage growth that has outstripped productivity increases. Cyprus will also need to replace jobs lost in construction.

\section{According to staff, implementation of the government's National Reform}

Programme has been slow. ${ }^{21}$ The program contains detailed measures in a broad range of areas, including measures to reform entitlement programs, the labor market, the business climate, infrastructure and education, all of which staff considered appropriate and consistent with the economy's medium and long-term needs. However, key reforms, such as health care reform, are likely to be delayed because of a lack of consensus among stakeholders and technical problems. Staff pushed for speedy implementation, in particular, the streamlining of red tape and bureaucracy, which, supported by a bloated civil service, was singled out by the private sector as the biggest impediment to competitiveness.

30. Wage increases must reflect productivity developments. Staff viewed the backward-looking automatic indexation mechanism (COLA) as having allowed wage increases to outstrip productivity, especially in the public sector, thereby hampering competitiveness. The authorities disagreed and were reluctant to consider changing this system in any way: the COLA is considered sacrosanct as it is seen to promote social cohesion and is widely credited - even by businesses - for engendering industrial-labor peace. Therefore they disagreed with staff's views that COLA should ideally be eliminated. Alternatively, staff emphasized that if COLA was to be preserved, it would be imperative to minimize its damaging effect by keeping inflation under control through productivityenhancing structural reforms including in public administration. It welcomed the willingness of labor unions, government, and businesses to follow through with the wage cuts determined by COLA in the second half of 2009. It noted, however, that COLA, as currently practiced, does not improve social cohesion as it covers and disproportionately benefits the richest 60 percent of employees mainly in the public sector and banks. Staff suggested that alternative measures could be considered to better achieve social cohesion, for instance, by targeting COLA more effectively.

\footnotetext{
${ }^{21}$ Lisbon Strategy Renewed National Reform Programme for the Republic of Cyprus, October 2008.
} 
Figure 7. Cyprus: Competitiveness and the Lisbon Agenda

There is scope to improve competitiveness.

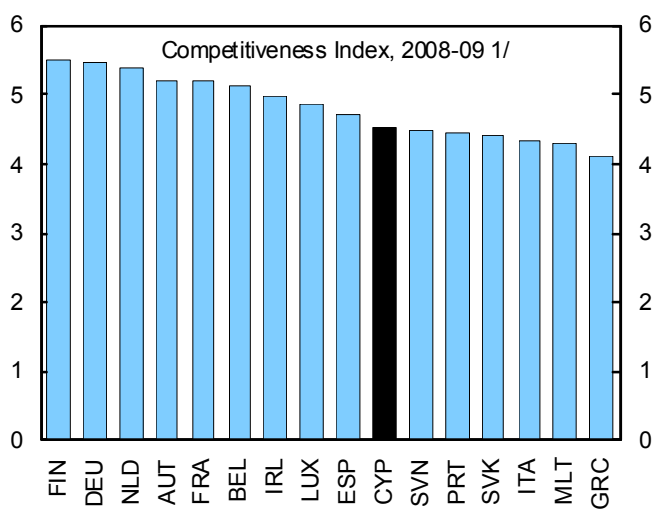

...especially on information society and enterprise environment

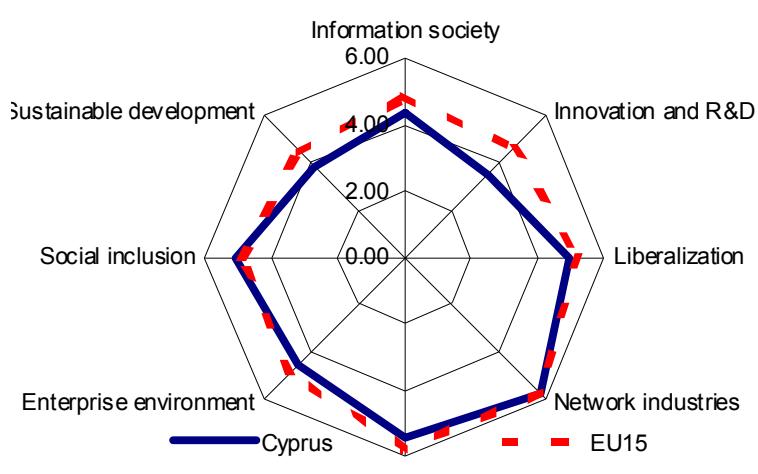

Financial services
Cyprus is lagging behind on Lisbon objectives..

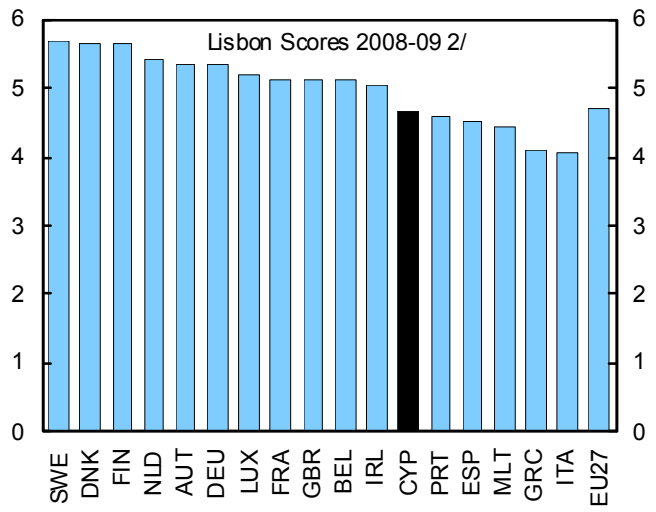

...the quality of institutions...

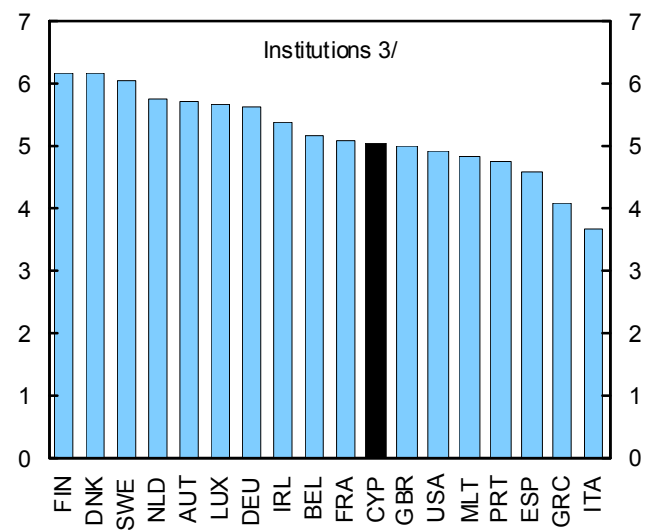

... and education.

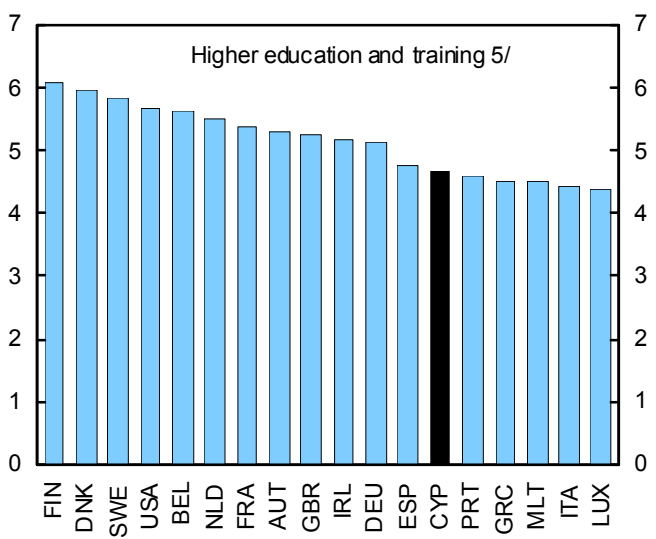

Sources: World Economic Forum

1/ The competitiveness index comprises the weighted average of indicators on institutions, infrastructure, macroeconomic stability, health and primary education, higher education and training, goods market efficiency, labor market efficiency, financial market sophistication, technological readiness, market size, business sophistication, and innovation.

2/ Lisbon scores are calculated as an unweighted average of the individual scores on information society, innovation and R\&D, liberalization, network industries, financial services, enterprise environment, social inclusion, and sustainable development.

3/ The institutional environment includes the legal framework, the efficiency of public and private institutions, i.e. excessive bureaucracy, overregulation, corruption, lack of transparency, etc. The higher the indicator, the better the institutions.

4/ Goods market efficiency meaures the impediments to business activity through government intervention such as distortionary or burdensome taxes and restrictive and discriminatory rules on foreign ownership or foreign direct invesment .

5/ Higher education and training indicates secondary and tertiary enrollment rates as well as the quality of education as assessed by the business community. 


\section{STAFF APPRAisal}

31. The global crisis has started to affect Cyprus. The economy has been relatively shielded from the crisis until now, largely because of a lesser reliance on exports, euro adoption, and a resilient financial sector which has not needed public capital injections. However, the overheating of the economy in 2007-08 has given rise to vulnerabilities which will need to be managed carefully as the economy slows down. The private sector is highly leveraged, and banks and households have large exposures to the property market which is beginning to correct itself. Balance sheets will therefore need to adjust to the new economic realities. The evaporation of growth is likely to worsen credit risk in the banking sector which, if they materialize, could have systemic implications given the size and concentration of banking sector. Moreover, fiscal policies are on an unsustainable path due to significant and permanent increases in spending at a time when revenues are declining due the economic cycle and a permanent correction in the property market. Finally, the large current account deficit - indicating both overheating and competitiveness problems and increasingly financed by non-resident deposit inflows - may not be sustainable. Going forward, therefore policies will need to mitigate short-term risks while ensuring medium-term sustainability.

\section{The government's fiscal objectives are appropriate but policies will need to be} strengthened to achieve those objectives. Given high import elasticities, a fiscal stimulus is less likely to be effective and could reduce investor confidence in fiscal sustainability. A conservative fiscal stance would support confidence in the public sector's ability to cope with financial sector distress. Without significant course correction in 2009-10, current policies could imply the beginning of an expansionary debt-deficit cycle which could become unsustainable. The budget deficit would need to decline by an estimated $1 / 2-3 / 4$ percent of GDP a year to achieve the government's own objective of budget balance over the medium term.

33. Fiscal adjustment should rely on reducing public consumption, especially the wage bill which accounts for a third of total spending. Policies could include hiring and wage controls and a broader public administration reform including the extension of flexicurity from the private to the public sector. Social support measures, including those introduced in the past, should be targeted to reach the truly needy, enhance social cohesion, and protect the budget. Temporary stimulus measures should be allowed to expire when recovery sets in. A medium-term budget framework aiming to contain spending below nominal GDP growth and control public sector employment should be implemented. While the passage of long-delayed pension reforms is commendable, additional reforms may be needed at some point to reduce budget spending, including increasing the retirement age, indexing benefits to prices, and better aligning public and private pension benefits.

34. Fiscal policy would be well served by a more effective management of public sector liabilities. The government's initiative in this regard are welcome and should be enhanced by transparently accounting for contingent liabilities which would need to be monitored carefully so that overall exposures do not deteriorate rapidly as economic conditions worsen. Public sector aid programs should be designed to protect competition and minimize moral hazard and adverse selection. 
35. The financial sector is holding up and risks (mainly credit risk) appear to be manageable. With assets of some 690 percent of GDP, financial sector problems can quickly become systemic and the top three banks are "too big to fail". Thus early detection of risks and intervention will be key to preserving financial sector stability. A resilient financial sector would also protect growth, enhance the growth potential of Cyprus, and facilitate external flows to finance the large current account deficits.

36. Banks, supervisors and the government have reacted appropriately to the crisis. The participation in the FSAP is welcome, as is the rapid progress in strengthening supervision and implementing the FSAP recommendations. However, there will be a need for continued vigilance and enhanced cross-border cooperation. Cyprus' reputation as a financial center depends on the continuation of an effective and arms length supervision by an independent and accountable central bank. The CBC should closely monitor developments in banks' funding, cross-border exposures, and counterparty risk management. In anticipation of a further deterioration of asset quality and, possibly, liquidity risk, it should require adequate capital buffers, particularly from systematically important banks. Loan-to-value ratios on second homes may need to be reviewed in line with property price developments, and foreclosure procedure would need to be shortened to allow for a more rapid property price correction and bank balance sheet adjustment.

\section{Further improvements to supervision and the safety net should be effected over}

the medium term. The stress testing framework should be expanded and enhanced. Supervisory resources must be bolstered. Over the medium term, a single supervisor for all credit institutions operating in Cyprus could enhance efficiency, and establish a level playing field. Given the integrated nature of the financial sector in Cyprus, a more integrated supervisory structure based in the CBC would be preferable to the current sectoral approach.

38. Improved competitiveness will assist recovery and enhance the growth potential. While Cyprus remains attractive to foreign investors due to strategic, historical, institutional and economic advantages, its ranking on global competitiveness indicators is low, reflecting in particular high wage growth compared to productivity increases. The National Reform Programme should be implemented. In particular, red tape and bureaucracy must be tackled as a matter of priority.

39. The deterioration in productivity and unit labor costs must be reversed. Ideally the COLA should be eliminated as it has resulted in wage increases larger than productivity, especially in the public sector, thereby hampering competitiveness. Alternatively, the damaging effect of COLA should be minimized by keeping inflation under control through productivity-enhancing structural reforms. In addition, amendments to the framework-for instance by more effectively targeting COLA — should be considered to better achieve social cohesion.

40. It is recommended that the next Article IV consultation take place on a 12-month cycle. 
Figure 8. Cyprus: Public Debt Sustainability: Bound Tests 1/ (Percent of GDP)

Baseline and historical scenarios

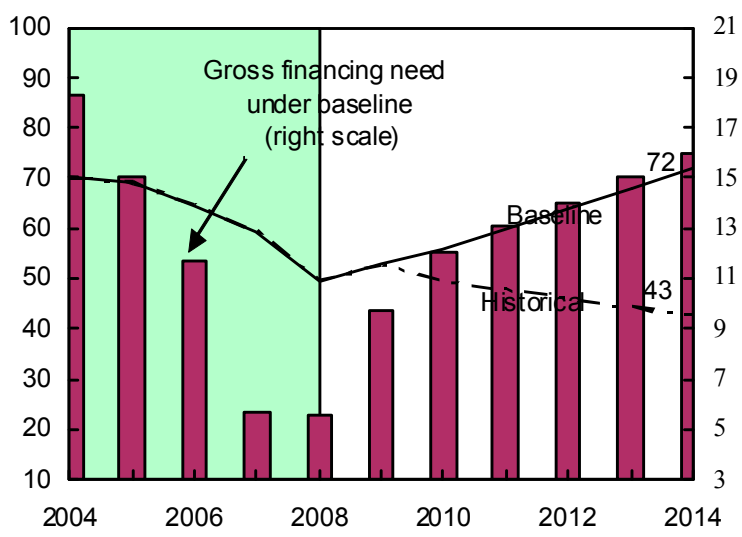

Growth shock (percent per year)

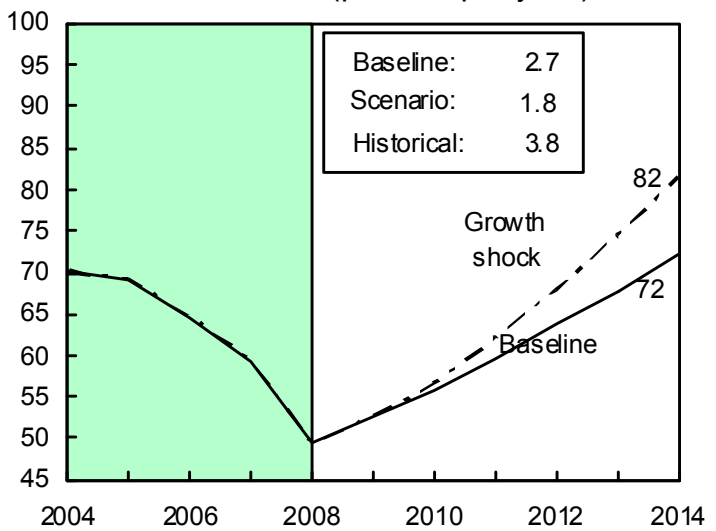

Combined shock 2/

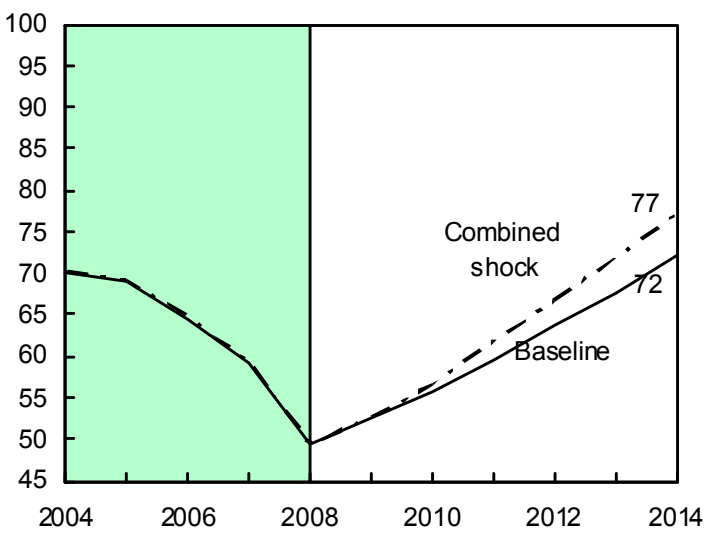

Interest rate shock (percent)

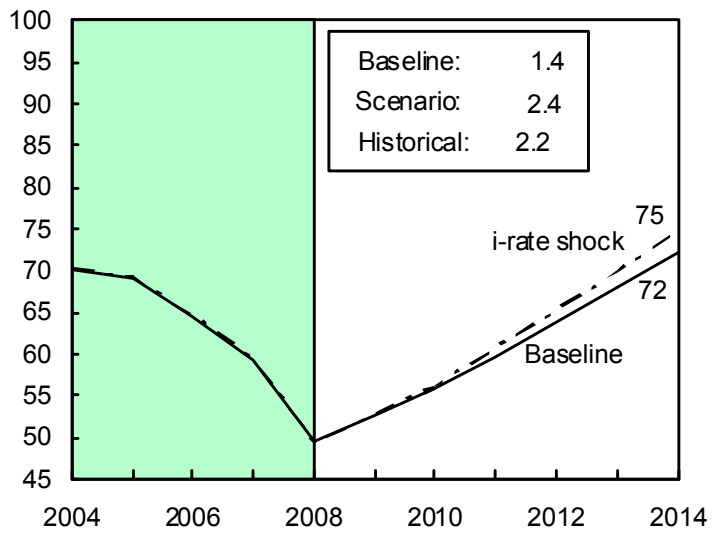

Primary balance shock and no policy change scenario (constant primary balance)

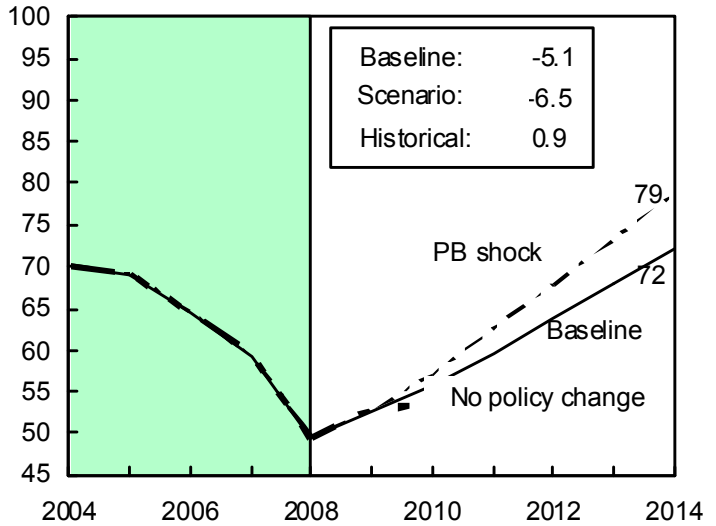

Real depreciation and contingent liabilities

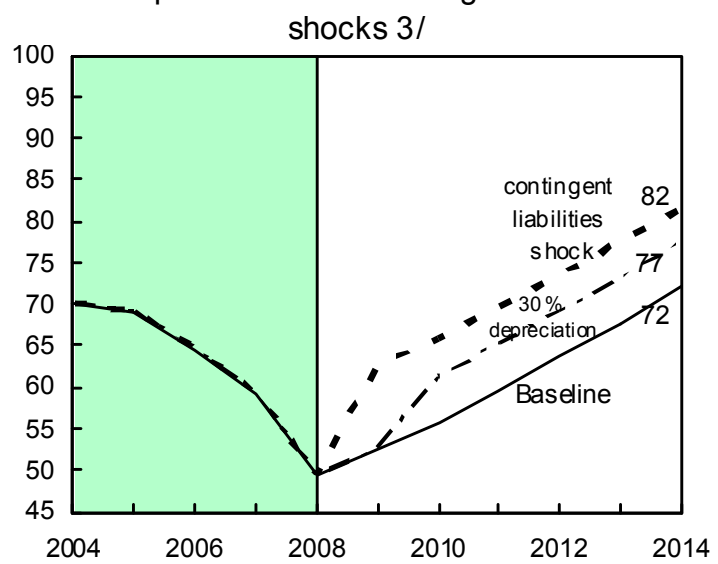

Sources: International Monetary Fund, country desk data, and staff estimates.

$1 /$ Shaded areas represent actual data. Individual shocks are permanent one-half standard deviation shocks. Figures in the boxes represent average projections for the respective variables in the baseline and scenario being presented. Ten-year historical average for the variable is also shown.

2/ Permanent $1 / 4$ standard deviation shocks applied to real interest rate, growth rate, and primary balance. $3 /$ One-time real depreciation of 30 percent and 10 percent of GDP shock to contingent liabilities occur in 2009, with real depreciation defined as nominal depreciation (measured by percentage fall in dollar value of local currency) minus domestic inflation (based on GDP deflator). 
Figure 9. Cyprus: External Debt Sustainability: Bound Tests 1/ (Net external debt, percent of GDP)
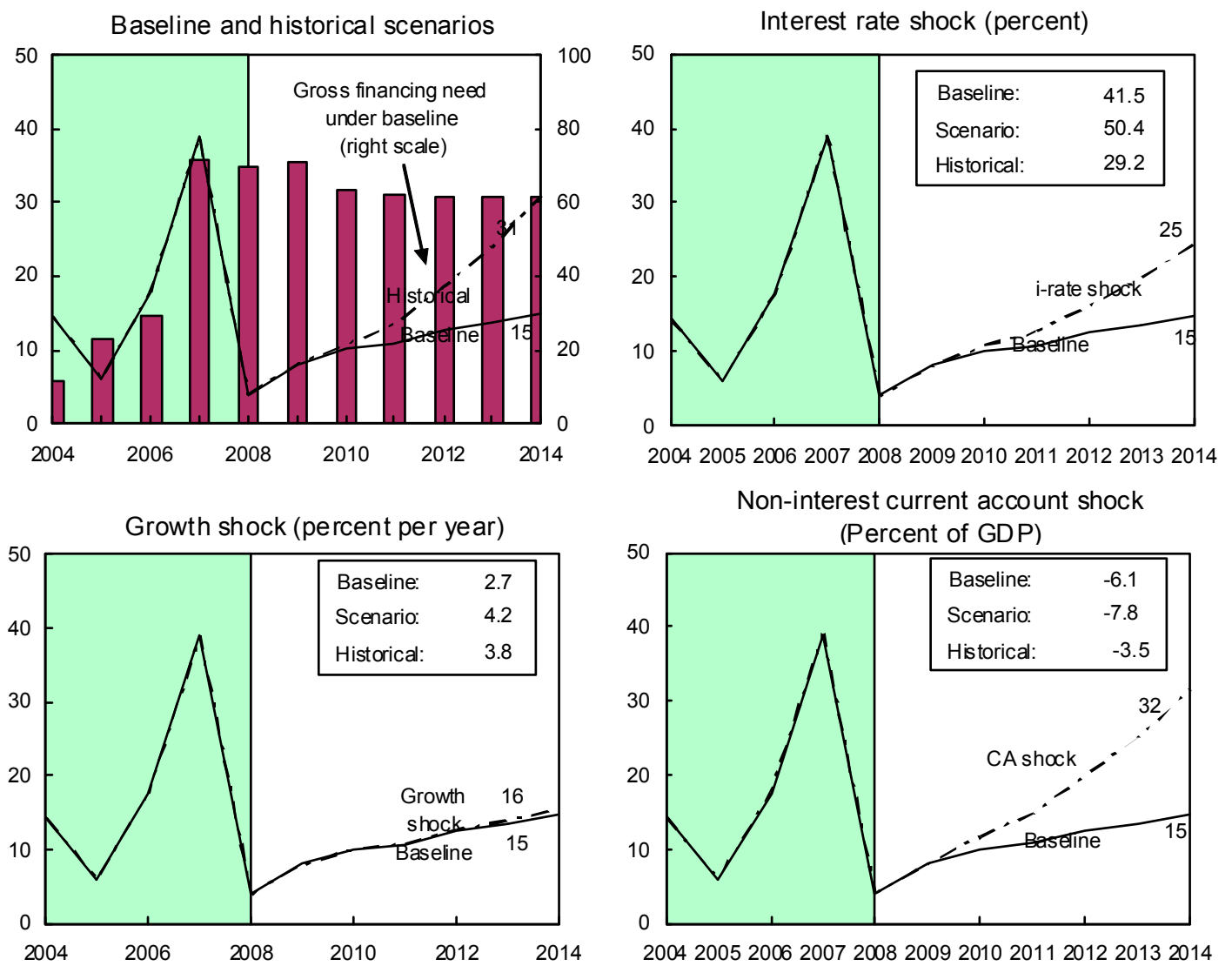

Combined shock $2 /$
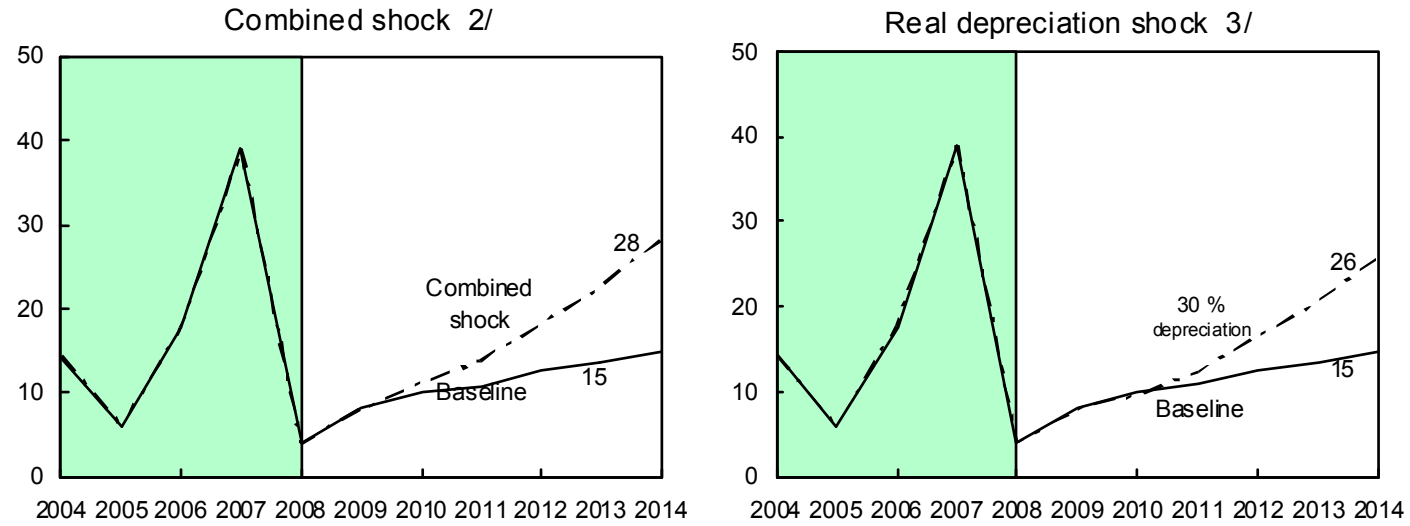

Sources: International Monetary Fund, Country desk data, and staff estimates.

$1 /$ The analysis uses net external debt, i.e. gross external debt excluding gross external assets in debt instruments. These assets include claims on affiliated enterprises from direct investment abroad, total debt securities from portfolio investment, as well as total trade credits, total loans, currency and deposits, and other assets from other investment. All data are taken from the as set side of international investment position. Net external debt declined sharply in 2008 as banks accumulated assets abroad.

2/ Shaded areas represent actual data. Individual shocks are permanent one-half standard deviation shocks. Figures in the boxes represent average projections for the respective variables in the baseline and scenario being presented. Ten-year historical average for the variable is also shown.

3/ Permanent 1/4 standard deviation shocks applied to real interest rate, growth rate, and current account balance.

4/ One-time real depreciation of 30 percent occurs in 2009. 
Table 1. Cyprus: Selected Economic Indicators, 2004-10

\begin{tabular}{|c|c|c|c|c|c|c|c|}
\hline & \multirow[t]{2}{*}{2004} & \multirow[t]{2}{*}{2005} & \multirow[t]{2}{*}{2006} & \multirow[t]{2}{*}{2007} & \multirow[t]{2}{*}{2008} & 2009 & 2010 \\
\hline & & & & & & \multicolumn{2}{|c|}{ Proj. } \\
\hline & \multicolumn{7}{|c|}{ (Annual percentage change) } \\
\hline Gross domestic product & 4.2 & 3.9 & 4.1 & 4.4 & 3.6 & 0.3 & 1.1 \\
\hline Domestic demand & 6.5 & 3.1 & 5.6 & 7.4 & 8.7 & -2.4 & 2.0 \\
\hline Private consumption & 6.3 & 4.0 & 4.5 & 8.2 & 7.9 & -0.3 & 1.2 \\
\hline Public consumption & -5.5 & 3.4 & 7.4 & 0.1 & 5.4 & 3.6 & 4.7 \\
\hline Gross investment & 20.1 & 0.0 & 7.7 & 11.2 & 14.0 & -13.3 & 2.3 \\
\hline Net exports & -2.3 & 0.8 & -1.4 & -3.0 & -5.3 & 3.1 & -1.0 \\
\hline Exports of goods and nonfactor services & 5.1 & 4.7 & 3.9 & 7.2 & -2.2 & -17.2 & 0.5 \\
\hline Imports of goods and nonfactor services & 9.6 & 3.1 & 6.6 & 12.5 & 7.6 & -18.8 & 2.6 \\
\hline Potential output & 4.2 & 4.2 & 4.2 & 3.3 & 3.2 & 2.1 & 2.4 \\
\hline Output gap & 0.2 & 0.0 & 0.0 & 1.1 & 1.5 & -0.3 & -1.6 \\
\hline Employment growth & 3.0 & 1.6 & 2.7 & 5.8 & 1.3 & 0.2 & 0.4 \\
\hline Unemployment rate (percent) & 4.7 & 5.3 & 4.6 & 3.9 & 3.7 & 5.6 & 5.9 \\
\hline Inflation (CPI index, end of period) & 3.9 & 1.4 & 1.5 & 3.7 & 1.8 & 0.9 & 1.4 \\
\hline Inflation (HICP, period average) & 1.9 & 2.0 & 2.2 & 2.2 & 4.4 & 0.9 & 1.5 \\
\hline \multirow[t]{2}{*}{ GDP deflator } & 3.2 & 2.3 & 3.0 & 3.4 & 4.8 & 0.9 & 1.5 \\
\hline & \multicolumn{7}{|c|}{ (Contributions to growth) } \\
\hline Domestic demand & 6.6 & 3.2 & 5.7 & 7.7 & 9.3 & -2.7 & 2.2 \\
\hline Private consumption & 4.1 & 2.6 & 3.0 & 5.4 & 5.4 & -0.2 & 0.9 \\
\hline Public consumption & -1.0 & 0.6 & 1.2 & 0.0 & 0.9 & 0.6 & 0.8 \\
\hline Gross investment & 3.5 & 0.0 & 1.5 & 2.3 & 3.0 & -3.1 & 0.5 \\
\hline \multirow[t]{2}{*}{ Net exports } & -2.4 & 0.7 & -1.6 & -3.2 & -5.8 & 3.0 & -1.1 \\
\hline & \multicolumn{7}{|c|}{ (Percent of GDP) } \\
\hline Gross domestic investment & 20.2 & 19.9 & 20.8 & 22.3 & 24.5 & 21.5 & 21.9 \\
\hline Of which: private & 16.1 & 17.0 & 18.2 & 19.8 & 20.8 & 17.1 & 17.2 \\
\hline Gross domestic saving & 15.2 & 14.0 & 13.7 & 10.6 & 6.2 & 11.3 & 11.7 \\
\hline \multicolumn{8}{|l|}{ General government public finance } \\
\hline Total revenue & 38.7 & 41.2 & 42.2 & 46.4 & 44.9 & 42.6 & 42.6 \\
\hline Total expenditure & 42.8 & 43.6 & 43.4 & 42.9 & 44.0 & 46.5 & 48.5 \\
\hline Overall balance & -4.1 & -2.4 & -1.2 & 3.4 & 0.9 & -3.9 & -5.9 \\
\hline Primary balance & -0.8 & 1.1 & 2.1 & 6.5 & 3.8 & -1.5 & -3.6 \\
\hline Structural overall balance & -4.2 & -2.4 & -1.2 & 2.9 & 0.3 & -3.8 & -5.2 \\
\hline Gross public debt $1 /$ & 70.2 & 69.1 & 64.6 & 59.4 & 49.4 & 52.7 & 55.6 \\
\hline \multicolumn{8}{|l|}{ External sector } \\
\hline Service balance & 22.9 & 22.7 & 23.6 & 23.6 & 20.8 & 20.0 & 20.1 \\
\hline Of which: Financial and insurance services (credit) & 1.9 & 2.2 & 2.9 & 4.9 & 6.7 & $\ldots$ & $\ldots$ \\
\hline Tourism (credit) & 16.3 & 16.2 & 15.8 & 15.6 & 14.3 & $\ldots$ & $\ldots$ \\
\hline Tourism (debit) & 5.8 & 6.5 & 6.5 & 8.5 & 8.1 & $\ldots$ & $\ldots$ \\
\hline Current account balance & -5.0 & -5.9 & -7.1 & -11.8 & -18.3 & -10.3 & -10.2 \\
\hline Of which: trade balance & -25.7 & -25.4 & -27.7 & -30.3 & -32.8 & -26.6 & -26.8 \\
\hline Capital and financial account & 4.1 & 4.9 & 7.1 & 13.0 & 18.4 & 10.3 & 10.2 \\
\hline Of which: foreign direct investment, net & 2.5 & 3.7 & 5.3 & 4.6 & 2.0 & 2.4 & 2.4 \\
\hline Portfolio investment, net $2 /$ & 7.2 & -0.8 & -0.9 & -2.1 & -75.5 & 0.1 & 0.1 \\
\hline Of which: other investment, net $2 /$ & -3.7 & 5.8 & 9.0 & 8.4 & 91.3 & 8.0 & 8.0 \\
\hline Social indicators & & & Year & Cyprus & & & \\
\hline GDP per capita, in current U.S. dollars & & & 2008 & 32,745 & & & \\
\hline Population, in thousands & & & 2008 & 761.1 & & & \\
\hline Population density, inhabitants per square kilometer & & & 2007 & 92 & & & \\
\hline Life expectancy (years at birth): males & & & 2006 & 77 & & & \\
\hline females & & & 2006 & 82 & & & \\
\hline Literacy, percent of persons aged 15 and above & & & 2006 & 96.8 & & & \\
\hline \multicolumn{8}{|l|}{ Memorandum item: } \\
\hline Nominal GDP (billions of euros) & 12.7 & 13.5 & 14.4 & 15.6 & 16.9 & 17.1 & 17.6 \\
\hline Deposit rates $3 /$ & 4.2 & 3.7 & 3.6 & 4.4 & 5.4 & 3.3 & $\ldots$ \\
\hline Lending rates $4 /$ & 7.9 & 6.7 & 6.8 & 6.3 & 7.0 & 6.9 & $\cdots$ \\
\hline Private credit growth $5 /$ & 6.0 & 6.0 & 12.6 & 22.7 & 28.6 & 20.4 & $\ldots$ \\
\hline Nominal effective exchange rate $(C P I, 2000=100)$ & 2.3 & 0.2 & 0.5 & 0.7 & 3.5 & $\ldots$ & $\cdots$ \\
\hline Real effective exchange rate $(\mathrm{CPI}, 2000=100)$ & 1.8 & -0.1 & 0.2 & 0.0 & 3.6 & $\cdots$ & $\cdots$ \\
\hline Real effective exchange rate (ULC, $2000=100$ ) & 12.1 & 9.8 & 4.3 & 7.0 & 5.1 & $\cdots$ & $\cdots$ \\
\hline
\end{tabular}

Sources: Ministry of Finance; Central Bank of Cyprus; World Bank, World Development Indicators; and IMF staff projections.

$1 /$ Gross public debt excluding intragovernmental debt and short-term liabilities of the Central Bank.

$2 / 2008$ data reflects the transactions between Greek banks and their subsidiaries in Cyprus.

3 / Since 2007, data refer to the average of MFI interest rates on euro-denominated deposits up to 1 year. Data for 2009 are as of May.

4/ Since 2007, data refer to the average of MFI interest rates on euro-denominated loans. Data for 2009 are as of May.

$5 /$ Data for 2009 are as of May. 
Table 2. Cyprus: Financial System, 2004-2008

(Billions of euros, unless otherwise noted)

\begin{tabular}{|c|c|c|c|c|c|}
\hline & 2004 & 2005 & 2006 & 2007 & 2008 \\
\hline \multicolumn{6}{|l|}{ Banking sector } \\
\hline \multicolumn{6}{|l|}{ Number } \\
\hline Credit Institutions & 401 & 390 & 333 & 212 & 162 \\
\hline Commercial banks & 14 & 14 & 40 & 42 & 43 \\
\hline Of which: Foreign-owned Subsidiaries & 4 & 4 & 9 & 10 & 9 \\
\hline Branches of Foreign Banks & 2 & 2 & 22 & 24 & 26 \\
\hline Specialized Institutions (priv ate) & 1 & 1 & 1 & 1 & 1 \\
\hline Specialized Institutions (state-owned) & 2 & 2 & 1 & 1 & 1 \\
\hline Cooperative credit institutions & 358 & 348 & 293 & 170 & 119 \\
\hline International Banking Units 1/ & 29 & 28 & $\ldots$ & $\ldots$ & $\ldots$ \\
\hline \multicolumn{6}{|l|}{ Total assets } \\
\hline Credit Institutions & 48.0 & 61.9 & 74.7 & 91.1 & 116.0 \\
\hline Commercial banks & 30.7 & 38.4 & 64.5 & 79.7 & 104.2 \\
\hline Of which: Foreign-owned Subsidiaries & 3.4 & 4.0 & 20.3 & 20.9 & 29.1 \\
\hline Branches of Foreign Banks & 0.4 & 0.4 & 4.0 & 10.4 & 9.7 \\
\hline Specialized Institutions (priv ate) & 0.0 & 0.0 & 0.0 & 0.0 & 0.0 \\
\hline Specialized Institutions (state-owned) & 1.3 & 1.4 & 1.3 & 1.3 & 1.3 \\
\hline Cooperative credit institutions & 8.1 & 9.1 & 10.3 & 11.4 & 11.9 \\
\hline International Banking Units 1/ & 9.2 & 14.4 & & $\ldots$ & \\
\hline \multicolumn{6}{|l|}{ Concentration $2 /$} \\
\hline Commercial banks & 4 & 3 & 8 & 9 & 8 \\
\hline Cooperative credit institutions & 52 & 51 & 49 & 45 & 41 \\
\hline International Banking Units /1 & 6 & 5 & $\ldots$ & $\ldots$ & $\ldots$ \\
\hline No. of bank branches & 470 & 451 & 468 & 474 & 496 \\
\hline No. of bank branches per 100,000 inhabitants & 63 & 59 & 60 & 60 & 63 \\
\hline \multicolumn{6}{|l|}{ Insurance sector $3 /$} \\
\hline Number & 39 & 39 & 41 & 41 & $\ldots$ \\
\hline Life insurance companies & 11 & 11 & 10 & 10 & $\ldots$ \\
\hline General insurance companies & 28 & 28 & 27 & 27 & $\ldots$ \\
\hline Composite companies & 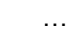 & $\ldots$ & 4 & 4 & \\
\hline Total assets & 2.8 & 3.4 & 3.9 & 4.2 & $\ldots$ \\
\hline Life insurance companies & 2.1 & 2.4 & 2.8 & 3.0 & $\ldots$ \\
\hline General insurance companies & 0.7 & 1.0 & 1.0 & 1.2 & $\ldots$ \\
\hline Composite companies & $\ldots$ & $\ldots$ & 0.3 & 0.3 & $\ldots$ \\
\hline \multicolumn{6}{|l|}{ Concentration 2/ } \\
\hline Life insurance companies & 4 & 4 & 4 & 4 & $\ldots$ \\
\hline General insurance companies & 8 & 8 & 8 & 8 & $\ldots$ \\
\hline Composite companies & & & 3 & 3 & $\ldots$ \\
\hline \multicolumn{6}{|l|}{ Securities sector } \\
\hline \multicolumn{6}{|l|}{ Number } \\
\hline Investment firms (market intermediaries) 4/ & 44 & 49 & 62 & 65 & 62 \\
\hline International collective investment schemes & 15 & 22 & 29 & 33 & $\ldots$ \\
\hline International financial companies 5/ & 50 & 43 & $\ldots$ & $\ldots$ & $\ldots$ \\
\hline of which Financial advisory firms 5/ & 41 & 36 & $\ldots$ & $\ldots$ & $\ldots$ \\
\hline international trustee services & 9 & 7 & $\ldots$ & $\ldots$ & $\ldots$ \\
\hline \multicolumn{6}{|l|}{ Total assets } \\
\hline Stock market capitalization & 7.8 & 10.9 & 12.4 & 20.2 & $\ldots$ \\
\hline International collective investment schemes $6 /$ & 0.2 & 0.1 & 0.3 & 0.3 & $\ldots$ \\
\hline
\end{tabular}

Sources: Central Bank of Cyprus; Cyprus Securities and Exchange Commission (CySEC); and Insurance Companies' Control Ser 1/ As from 1 January 2006, former IBUs have been incorporated into aggregate banking system data. 2/ Number of institutions with 75 percent of total assets.

3/ Composite insurance companies and EU branches are not included except for the years 2006 and 2007, the 4 composite insurance companies operating in Cyprus are separately shown.

4/ Firms licensed by CySEC under 2002 investment firms law.

5/ From 2003 international financial companies refer to financial advisory firms plus intemational trustee services companies. 
Table 3. Cyprus: Financial Sector Measures Taken by the Authorities

Crisis Management: A crisis management law is being prepared with EC consultation. This would empower the government to preemptively address liquidity or insolvency problems in financial institutions through government loans, government guarantees of loans and issuance of government bonds to credit institutions; recapitalization of financial institutions in exchange for an ownership stake; and purchase of a financial institution's assets.

Deposit Insurance: The deposit guarantee scheme is being expanded to increase the statutory deposit protection coverage per depositor and per bank to $€ 100,000$ for deposits in all currencies. The payout period will be reduced in line with EU regulations. Since December 2008, the capital of the Deposit Protection Fund is being gradually raised to $€ 100$ million by 2012 with higher contributions from banks. The maximum amount of required special and/or supplementary contributions and the ceiling on borrowing by the Fund have been raised.

Emergency Liquidity Assistance (ELA): There has been progress in establishing guidance for ELA. The CBC has identified eligible collateral for ELA in bank balance sheets. Applicable haircuts will be determined through a last minute evaluation of collateral. The policy framework for the provision of ELA by the CBC is ready to be submitted to the CBC Board for approval; the operational framework is under preparation. The process for establishing a legal and regulatory framework for covered bonds has been initiated to facilitate banks' access to ECB facilities. A draft law is being prepared.

Bank Supervision: The CBC has been implementing the EU regulatory framework and the core principles for effective banking supervision issued by the Basel Committee. Since October 2008, the frequency of liquidity returns reporting has been increased. The CBC plans to implement the CEBS's guidance on liquidity buffer and survival period. In line with FSAP recommendations, the CBC has increased the frequency of reporting capital adequacy and large exposure limits, reduced limits on connected lending, and increased monetary penalties. The CBC has participated in the activities of the Committee of European Banking Supervisors (CEBS) and placed emphasis on the timely adoption of EU Directives and the recommendations of the CEBS and of the Basel Committee on Banking Supervision.

Cross-border Supervision: The CBC is collaborating with other supervisors within the framework established in Memoranda of Understanding and EU-wide cross-border cooperation and arrangements. In particular, there is frequent exchange of information and consultation with Greek supervisors, including joint onsite examinations. Cooperation will be further enhanced by the establishment of supervisory colleges between home and host supervisors. The CBC, as home supervisors, will establish colleges for the Bank of Cyprus and Marfin Popular Bank, and as host supervisors will collaborate with home supervisors. The CBC plans to implement the CEBS's Liquidity Identify Card which aims to provide supervisors of European cross-border banking groups with a single prudential language to enable meaningful exchanges of information, in particular within colleges of supervisors.

Bank Resolution: The CBC plans to adopt the EC's policy on early intervention measures to be issued at end-2009.

Source: National Authorities. 
Table 4. Cyprus: Financial Soundness Indicators for Banks, 2005-2008 1/

(Percent)

\begin{tabular}{|c|c|c|c|c|c|}
\hline & 2005 & 2006 & 2007 & 2008 & \\
\hline & & & & CBCSDI & $\mathrm{DC}$ \\
\hline Core Set & & & & & \\
\hline Regulatory capital to risk-weighted assets & 12.4 & 12.4 & 12.8 & 11.0 & $\ldots$ \\
\hline Regulatory Tier I capital to risk-weighted assets & 10.0 & 10.8 & 10.4 & 8.6 & \\
\hline Non performing loans net of provisions to capital 2/ & 34.8 & 20.4 & 9.0 & 16.2 & 7.6 \\
\hline Nonperforming loans to total gross loans $3 /$ & 7.1 & 5.4 & 3.4 & 3.6 & 3.2 \\
\hline Sectoral distribution of loans to total loans & & & & & \\
\hline Residents & 47.9 & 42.6 & 39.3 & 39.5 & 54.0 \\
\hline Loans to Insurance corporations & $\ldots$ & $\ldots$ & $\ldots$ & $\ldots$ & $\ldots$ \\
\hline Loans to Domestic and foreign credit institutions & $\ldots$ & $\ldots$ & $\ldots$ & $\ldots$ & $\ldots$ \\
\hline Loans to Non-financial corporations & 19.4 & 17.4 & 17.6 & 21.4 & 30.2 \\
\hline Loans to Households & $\ldots$ & $\ldots$ & $\ldots$ & 12.4 & 16.4 \\
\hline Consumer credit 4/ & $\ldots$ & $\ldots$ & $\ldots$ & $\ldots$ & $\ldots$ \\
\hline Lending for house purchase & $\ldots$ & $\ldots$ & $\ldots$ & $\ldots$ & $\ldots$ \\
\hline Non residents & 52.1 & 57.4 & 60.7 & 60.5 & 46.0 \\
\hline Return on assets & 0.8 & 1.4 & 2.3 & 1.0 & 1.6 \\
\hline Return on equity & 14.1 & 25.5 & 37.3 & 14.5 & 18.8 \\
\hline Interest margin to gross income & 66.2 & 66.1 & 55.9 & 67.9 & 59.0 \\
\hline Noninterest expenses to gross income & 59.1 & 49.0 & 42.6 & 52.1 & 35.2 \\
\hline Liquid assets to total assets (broad measure) & $\ldots$ & $\ldots$ & $\ldots$ & 42.2 & 43.3 \\
\hline Liquid assets to total assets (core measure) & 29.5 & 31.1 & 29.5 & 27.6 & 30.3 \\
\hline Liquid assets to short-term liabilities (broad measure) & $\ldots$ & $\ldots$ & $\ldots$ & 53.8 & 56.8 \\
\hline Liquid assets to short-term liabilities (core measure) & 34.9 & 37.1 & 35.9 & 35.2 & 39.8 \\
\hline Net open position in foreign exchange to capital & 2.0 & 2.1 & 1.4 & 0.8 & $\ldots$ \\
\hline Optional Indicators & & & & & \\
\hline Trading income to total income & 5.7 & 7.5 & 9.1 & 1.8 & 11.5 \\
\hline Personnel expenses to noninterest expenses & 62.2 & 62.9 & 57.6 & 58.1 & 64.9 \\
\hline Customer deposits to total (non-interbank) loans & 134.7 & 132.2 & 122.7 & 94.2 & 103.8 \\
\hline
\end{tabular}

Source: Central Bank of Cyprus.

1/ Data for 2005 onwards are for deposit-takers compiled on a domestically-controlled, cross-border consolidation basis (DCCB) and do not include the cooperative credit institutions and foreign-controlled banks. The ratio of regulatory capital to risk-weighted assets compiled on a cross-border and cross-sector consolidation basis for all domestically-incorporated (CBCSDI) deposit-takers, which exclude the cooperative credit institutions but include the former International Banking Units is 13.4 percent, 13.2 percent and 12.5 percent for 2005-07 respectively. Similarly, on a cross-border and cross-sector basis, the ratio of regulatory Tier 1 capital to risk-weighted assets was 10.2 percent 10.2 percent and 10.3 percent for $2005-07$ respectively.

2/ Data for 2008 and onwards are for deposit-takers compiled on a cross-border and cross-sector for all domestically incorporated (CBCSDI) basis as well as on a domestic consolidation (DC) basis. Due to methodological changes the data for 2008 is not comparable with historical data.

3/ The numbers are not fully comparable over time. The threshold for classifying loans as non-performing was changed from 6 months in arrears to 3 months in 2006. Data 2005 onwards are compled according to the methodology and specifications provided in the IMF "Compilation Guide on Financial Soundness Indicators." The decline in nonperforming loan (NPL) ratios since 2005 reflects stricter lending criteria, repayments and write-offs of NPLs as well as denominator effects (growth in capital/loans).

4/ All non-mortgage household loans. 
Table 4 (contd.): Cyprus: Financial Soundness Indicators for Credit Cooperatives, 2005-08

\begin{tabular}{|c|c|c|c|c|}
\hline \multicolumn{5}{|c|}{ (Percent) } \\
\hline & 2005 & 2006 & 2007 & 2008 \\
\hline \multicolumn{5}{|l|}{ Core Set } \\
\hline Regulatory capital to risk-weighted assets & 12.1 & 13.8 & $\ldots$ & $\ldots$ \\
\hline Regulatory Tier I capital to risk-weighted assets & 12.1 & 13.8 & $\ldots$ & $\ldots$ \\
\hline Nonperforming loans net of provisions to capital $1 /$ & $\ldots$ & $\ldots$ & $\ldots$ & 8.3 \\
\hline Nonperforming loans to total gross loans $1 /$ & $\ldots$ & $\ldots$ & $\ldots$ & 1.9 \\
\hline Residents & 99.9 & 99.9 & 99.9 & 99.9 \\
\hline Insurance corporations & 0.0 & 0.0 & 0.0 & 0.0 \\
\hline Domestic and foreign credit institutions & 27.3 & 30.8 & 28.7 & 20.4 \\
\hline Non-financial corporations & 3.3 & 3.9 & 6.2 & 7.9 \\
\hline Households & 67.4 & 63.6 & 63.8 & 70.5 \\
\hline Consumer credit 2/ & 22.7 & 20.9 & 20.1 & 22.0 \\
\hline Lending for house purchase & 22.9 & 22.7 & 25.0 & 28.9 \\
\hline Nonresidents & 0.1 & 0.1 & 0.1 & 0.1 \\
\hline Return on assets & 0.6 & 0.7 & 0.7 & 0.4 \\
\hline Return on equity & 8.4 & 9.4 & 9.4 & 5.0 \\
\hline Interest margin to gross income & 158.5 & 151.1 & 85.7 & 85.7 \\
\hline Non-interest expenses to gross income & 135.0 & 115.6 & 65.7 & 81.0 \\
\hline Liquid assets to total assets & 26.8 & 29.5 & 28.5 & 20.6 \\
\hline Liquid assets to short-term liabilities & 28.7 & 26.5 & 32.7 & 22.4 \\
\hline Net open position in foreign exchange to capital & 0.0 & 0.1 & -0.2 & -0.1 \\
\hline \multicolumn{5}{|l|}{ Encouraged Set } \\
\hline Personnel expenses to non-interest expenses & $\ldots$ & 40.2 & 40.5 & 39.1 \\
\hline Customer deposits to total (non-interbank) loans & 129.2 & 133.9 & 131.4 & 116.9 \\
\hline Large exposures to capital & $\ldots$ & $\ldots$ & $\ldots$ & $\ldots$ \\
\hline Spread between reference lending and deposit rates & 1.8 & 1.9 & 1.6 & 2.1 \\
\hline Residential real estate loans to total loans & 32.0 & 32.0 & 33.3 & 33.8 \\
\hline Commercial real estate loans to total loans & 17.5 & 17.3 & 16.5 & 16.9 \\
\hline
\end{tabular}

Source: Authority for the Supervision and Development of Cooperative Societies.

$1 /$ Non-performing loan data available only from 2008.

2/ All loans to households without mortgage on dwelling. 
Table 5. Cyprus: Medium-Term Macroeconomic Framework, 2007-14

\begin{tabular}{|c|c|c|c|c|c|c|c|c|}
\hline & 2007 & 2008 & 2009 & 2010 & 2011 & 2012 & 2013 & 2014 \\
\hline & & & \multicolumn{6}{|c|}{ Projections } \\
\hline & \multicolumn{8}{|c|}{ (Percentage change, unless otherwise noted) } \\
\hline Gross domestic product & 4.4 & 3.6 & 0.3 & 1.1 & 2.7 & 3.3 & 3.3 & 3.3 \\
\hline Domestic demand & 7.4 & 8.7 & -2.4 & 2.0 & 2.8 & 3.4 & 3.6 & 3.6 \\
\hline Private consumption & 8.2 & 7.9 & -0.3 & 1.2 & 2.1 & 3.0 & 3.2 & 3.2 \\
\hline Public consumption & 0.1 & 5.4 & 3.6 & 4.7 & 3.9 & 3.5 & 3.2 & 3.1 \\
\hline Gross investment & 11.2 & 14.0 & -13.3 & 2.3 & 4.5 & 4.6 & 5.1 & 5.7 \\
\hline Exports of goods and nonfactor services & 7.2 & -2.2 & -17.2 & 0.5 & 3.7 & 5.5 & 5.7 & 6.1 \\
\hline Imports of goods and nonfactor services & 12.5 & 7.6 & -18.8 & 2.6 & 3.9 & 5.3 & 5.9 & 6.3 \\
\hline Potential output & 3.3 & 3.2 & 2.1 & 2.4 & 2.9 & 2.9 & 3.0 & 3.0 \\
\hline Output gap (percent) & 1.1 & 1.5 & -0.3 & -1.6 & -1.8 & -1.5 & -1.2 & -0.8 \\
\hline Employment growth & 5.8 & 1.3 & 0.2 & 0.4 & 1.0 & 1.5 & 1.5 & 1.5 \\
\hline Unemployment rate (percent) & 3.9 & 3.7 & 5.6 & 5.9 & 5.2 & 4.7 & 4.3 & 3.9 \\
\hline Inflation (HICP, period average) & 2.2 & 4.4 & 0.9 & 1.5 & 2.3 & 2.5 & 2.7 & 2.8 \\
\hline \multirow[t]{2}{*}{ GDP deflator } & 3.4 & 4.8 & 0.9 & 1.5 & 2.3 & 2.5 & 2.7 & 2.8 \\
\hline & \multicolumn{8}{|c|}{ (Contributions to growth) } \\
\hline Domestic demand & 7.7 & 9.3 & -2.7 & 2.2 & 3.1 & 3.7 & 4.0 & 4.0 \\
\hline Private consumption & 5.4 & 5.4 & -0.2 & 0.9 & 1.5 & 2.1 & 2.3 & 2.2 \\
\hline Public consumption & 0.0 & 0.9 & 0.6 & 0.8 & 0.7 & 0.6 & 0.6 & 0.6 \\
\hline Gross investment & 2.3 & 3.0 & -3.1 & 0.5 & 0.9 & 1.0 & 1.1 & 1.2 \\
\hline \multirow[t]{2}{*}{ Net exports } & -3.2 & -5.8 & 3.0 & -1.1 & -0.5 & -0.4 & -0.7 & -0.7 \\
\hline & \multicolumn{8}{|c|}{ (Percent of GDP) } \\
\hline Gross domestic investment & 22.3 & 24.5 & 21.5 & 21.9 & 21.7 & 21.8 & 21.8 & 21.8 \\
\hline Gross domestic saving & 10.6 & 6.2 & 11.3 & 11.7 & 11.7 & 11.9 & 12.0 & 12.1 \\
\hline \multicolumn{9}{|l|}{ General government public finance } \\
\hline Total revenue & 46.4 & 44.9 & 42.6 & 42.6 & 42.7 & 42.8 & 42.8 & 42.8 \\
\hline Total expenditure & 42.9 & 44.0 & 46.5 & 48.5 & 49.5 & 50.1 & 50.7 & 51.2 \\
\hline Overall balance & 3.4 & 0.9 & -3.9 & -5.9 & -6.8 & -7.2 & -7.8 & -8.3 \\
\hline Primary balance & 6.5 & 3.8 & -1.5 & -3.6 & -4.5 & -5.1 & -5.8 & -6.4 \\
\hline Structural overall balance & 2.9 & 0.3 & -3.8 & -5.2 & -6.0 & -6.6 & -7.3 & -8.0 \\
\hline Gross public debt $1 /$ & 59.4 & 49.4 & 52.7 & 55.6 & 59.8 & 63.7 & 67.8 & 72.2 \\
\hline \multicolumn{9}{|l|}{ External sector } \\
\hline Current account balance & -11.8 & -18.3 & -10.3 & -10.2 & -10.1 & -9.9 & -9.8 & -9.7 \\
\hline Of which: trade balance & -30.3 & -32.8 & -26.6 & -26.8 & -27.3 & -27.9 & -28.3 & -28.8 \\
\hline Capital and Financial account & 13.0 & 18.4 & 10.1 & 10.1 & 9.9 & 9.8 & 9.7 & 9.8 \\
\hline Of which: foreign direct investment, net & 4.6 & 2.0 & 2.4 & 2.4 & 2.6 & 2.9 & 2.9 & 2.9 \\
\hline Of which: other investment, net $2 /$ & 8.4 & 91.3 & 8.0 & 8.0 & 7.9 & 7.9 & 7.9 & 7.9 \\
\hline \multicolumn{9}{|l|}{ Memorandum item: } \\
\hline Nominal GDP (billions of euros) & 15.6 & 16.9 & 17.1 & 17.6 & 18.5 & 19.6 & 20.7 & 22.0 \\
\hline Euro Area GDP growth & 2.7 & 0.8 & -4.8 & -0.3 & 1.4 & 1.8 & 2.0 & 2.2 \\
\hline Euro Area inflation & 2.1 & 3.3 & 0.2 & 0.7 & 0.9 & 1.1 & 1.3 & 1.5 \\
\hline
\end{tabular}

Sources: Ministry of Finance; Central Bank of Cyprus; World Bank, World Development Indicators; and IMF staff projections.

$1 /$ Excludes intragovernmental debt and short-term liabilities of the Central Bank.

2/ 2008 data reflects the transactions between Greek banks and their subsidiaries in Cyprus. 
Table 6. Cyprus: Balance of Payments, 2007-14 (Percent of GDP, unless otherwise indicated)

\begin{tabular}{|c|c|c|c|c|c|c|c|c|}
\hline & 2007 & 2008 & 2009 & 2010 & 2011 & 2012 & 2013 & 2014 \\
\hline & & & \multicolumn{6}{|c|}{ Projections } \\
\hline Current account balance & -11.8 & -18.3 & -10.3 & -10.2 & -10.1 & -9.9 & -9.8 & -9.7 \\
\hline Trade balance & -30.3 & -32.8 & -26.6 & -26.8 & -27.3 & -27.9 & -28.3 & -28.8 \\
\hline Exports & 7.0 & 6.8 & 4.6 & 4.8 & 5.0 & 5.2 & 5.3 & 5.5 \\
\hline Imports & -37.2 & -39.5 & -31.1 & -31.6 & -32.3 & -33.1 & -33.6 & -34.3 \\
\hline Of which: Fuel and lubricants & -6.2 & -6.5 & -3.7 & -4.0 & -4.0 & -3.9 & -4.1 & -4.3 \\
\hline Non-oil imports & -31.1 & -33.1 & -27.4 & -27.6 & -28.3 & -29.1 & -29.5 & -30.0 \\
\hline Services & 23.6 & 20.8 & 20.0 & 20.1 & 21.6 & 22.0 & 22.3 & 22.7 \\
\hline Exports & 41.1 & 38.0 & 35.4 & 35.5 & 36.9 & 37.4 & 37.7 & 38.1 \\
\hline Of which: Travel (mainly tourism) & 12.6 & 11.0 & 8.9 & 8.7 & 8.7 & 8.7 & 8.5 & 8.4 \\
\hline Financial services and insurance services & 3.9 & 5.1 & 4.8 & 4.8 & 5.1 & 5.2 & 5.3 & 5.5 \\
\hline 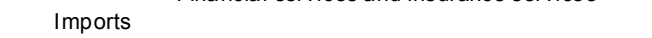 & -17.6 & -17.2 & -15.4 & -15.4 & -15.4 & -15.4 & -15.3 & -15.3 \\
\hline Investment income, net & -5.0 & -6.1 & -3.5 & -3.4 & -4.5 & -4.2 & -4.0 & -3.8 \\
\hline Transfers, net & 0.0 & -0.2 & -0.2 & 0.0 & 0.1 & 0.3 & 0.2 & 0.2 \\
\hline Capital and Financial account balance 1/ & 13.0 & 18.4 & 10.1 & 10.1 & 9.9 & 9.8 & 9.7 & 9.8 \\
\hline Capital account, net & 0.0 & 0.1 & 0.0 & 0.0 & 0.1 & 0.1 & 0.1 & 0.1 \\
\hline Direct foreign investment, net & 4.6 & 2.0 & 2.4 & 2.4 & 2.6 & 2.9 & 2.9 & 2.9 \\
\hline Portfolio investment, net 2/ & -2.1 & -75.5 & 0.1 & 0.1 & 0.3 & 0.3 & 0.3 & 0.3 \\
\hline Other investment, net 2/ & 8.4 & 91.3 & 8.0 & 8.0 & 7.9 & 7.9 & 7.9 & 7.9 \\
\hline Reserve assets & 1.4 & 1.6 & 0.0 & 0.0 & 0.0 & 0.0 & 0.0 & 0.0 \\
\hline Net errors and omissions & -1.2 & 0.0 & 0.0 & 0.0 & 0.0 & 0.0 & 0.0 & 0.0 \\
\hline Change in official reserves $3 / 4 /$ & 1.8 & -20.1 & -0.3 & 0.0 & 0.0 & 0.0 & 0.0 & 0.0 \\
\hline \multicolumn{9}{|l|}{ Memorandum items: } \\
\hline Gross official reserves (billions of U.S. dollars, end-of-period) & 6.1 & 1.1 & 1.0 & 1.0 & 1.0 & 1.0 & 1.0 & 1.0 \\
\hline Months of imports of goods and services & 6.2 & 0.9 & 1.1 & 1.1 & 1.0 & 0.9 & 0.9 & 0.8 \\
\hline Gross reserves (includes banks, billions of U.S. dollars, end-of- & 25.6 & 22.9 & 23.9 & 24.9 & 25.9 & 26.9 & 27.9 & 28.9 \\
\hline Months of imports of goods and services & 36.0 & 28.6 & 35.9 & 36.2 & 35.3 & 34.1 & 33.0 & 31.7 \\
\hline Import volume (percentage change) & 19.9 & 15.0 & -16.8 & 2.2 & 4.3 & 6.5 & 6.2 & 6.6 \\
\hline Partner country growth & 3.2 & 1.4 & -2.5 & -0.1 & 1.8 & 2.4 & 2.5 & 2.6 \\
\hline Export market share $(2000=100)$ & 83.0 & 78.4 & 69.1 & 69.2 & 69.4 & 69.9 & 70.4 & 70.9 \\
\hline Total external debt $5 /$ & 124.4 & 116.2 & 117.3 & 118.2 & 119.3 & 120.4 & 121.5 & 122.7 \\
\hline Of which: Private (banks) & 100.5 & 90.4 & $\ldots$ & $\ldots$ & $\ldots$ & $\ldots$ & $\ldots$ & $\ldots$ \\
\hline Short-term debt & 56.8 & 52.3 & $\ldots$ & $\ldots$ & $\ldots$ & $\ldots$ & $\ldots$ & $\ldots$ \\
\hline Of which: Private (non-banks) & 3.7 & 4.7 & $\ldots$ & $\ldots$ & $\ldots$ & $\ldots$ & $\ldots$ & $\ldots$ \\
\hline Total external debt, including non-resident deposits $5 /$ & 354.0 & 421.4 & 437.1 & 464.0 & 473.3 & 479.2 & 483.9 & 487.6 \\
\hline Net external debt $5 /$ & 39.0 & 4.0 & 8.1 & 10.0 & 10.8 & 12.6 & 13.5 & 14.8 \\
\hline Net International Investment Position & 12.7 & 4.1 & $\ldots$ & $\ldots$ & $\ldots$ & $\ldots$ & $\ldots$ & $\ldots$ \\
\hline Gross domestic product (billions of U.S. dollars) & 21.4 & 24.9 & 23.2 & 24.1 & 25.3 & 26.9 & 28.5 & 30.2 \\
\hline
\end{tabular}

Sources: Central Bank of Cyprus; and IMF staff estimates and projections.

1/ Includes financial derivatives.

2/ 2008 data reflects the transactions between Greek banks and their subsidiaries in Cyprus.

$3 /$ Includes valuation effects.

4/ Break in the series due to the change in the definition of residency as of Euro adoption in 2008

$5 /$ Total external debt is assumed to grow in line with non-resident deposit inflows, public debt projections and domestic credit growth. Net external debt assumes that nonresident deposits are fully invested abroad. 
Table 7. Cyprus: General Government Accounts, 2007-14 1/

(Percent of GDP, unless otherwise indicated)

\begin{tabular}{|c|c|c|c|c|c|c|c|c|}
\hline & 2007 & 2008 & 2009 & 2010 & 2011 & 2012 & 2013 & 2014 \\
\hline & & & \multicolumn{6}{|c|}{ Projections } \\
\hline & \multicolumn{8}{|c|}{ Baseline Scenario } \\
\hline Total Revenue & 46.4 & 44.9 & 42.6 & 42.6 & 42.7 & 42.8 & 42.8 & 42.8 \\
\hline Tax Revenue & 33.7 & 31.8 & 28.7 & 28.9 & 29.0 & 29.1 & 29.3 & 29.3 \\
\hline Taxes on production and imports & 20.0 & 18.7 & 16.9 & 17.0 & 16.9 & 17.0 & 17.1 & 17.2 \\
\hline Current taxes on income, wealth, property, etc & 14.0 & 13.1 & 11.8 & 11.9 & 12.1 & 12.1 & 12.1 & 12.2 \\
\hline Capital taxes & 0.0 & 0.0 & 0.0 & 0.0 & 0.0 & 0.0 & 0.0 & 0.0 \\
\hline Social Contributions & 7.7 & 8.3 & 9.2 & 9.7 & 9.8 & 9.8 & 9.8 & 9.8 \\
\hline Property income & 0.7 & 1.3 & 1.2 & 0.8 & 0.7 & 0.7 & 0.6 & 0.6 \\
\hline Other & 4.3 & 3.5 & 3.5 & 3.2 & 3.2 & 3.2 & 3.2 & 3.1 \\
\hline Total expenditure & 42.9 & 44.0 & 46.5 & 48.5 & 49.5 & 50.1 & 50.7 & 51.2 \\
\hline Current Expenditure & 39.1 & 41.0 & 43.3 & 45.0 & 46.0 & 46.5 & 47.2 & 47.7 \\
\hline Compensation of Employees & 14.2 & 14.3 & 15.0 & 15.5 & 15.6 & 15.6 & 15.6 & 15.6 \\
\hline Intermediate consumption & 5.1 & 5.3 & 5.7 & 6.0 & 6.1 & 6.1 & 6.1 & 6.1 \\
\hline Social payments & 11.7 & 12.7 & 13.7 & 14.5 & 15.0 & 15.5 & 16.0 & 16.5 \\
\hline Interest expenditure & 3.1 & 2.9 & 2.4 & 2.3 & 2.2 & 2.1 & 2.1 & 2.0 \\
\hline Subsidies & 0.4 & 0.4 & 0.5 & 0.5 & 0.4 & 0.4 & 0.4 & 0.4 \\
\hline Other & 5.2 & 5.5 & 6.1 & 6.4 & 6.6 & 6.8 & 7.0 & 7.1 \\
\hline Capital Expenditure & 2.9 & 3.0 & 3.2 & 3.5 & 3.5 & 3.5 & 3.5 & 3.5 \\
\hline Overall balance & 3.4 & 0.9 & -3.9 & -5.9 & -6.8 & -7.2 & -7.8 & -8.3 \\
\hline Primary balance & 6.5 & 3.8 & -1.5 & -3.6 & -4.5 & -5.1 & -5.8 & -6.4 \\
\hline Structural balance & 2.9 & 0.3 & -3.8 & -5.2 & -6.0 & -6.6 & -7.3 & -8.0 \\
\hline Public debt 2/ & 59.4 & 49.4 & 52.7 & 55.6 & 59.8 & 63.7 & 67.8 & 72.2 \\
\hline \multicolumn{9}{|l|}{ Memorandum items: } \\
\hline Total revenue excluding income and property tax & 32.4 & 31.8 & 30.8 & 30.7 & 30.6 & 30.7 & 30.7 & 30.7 \\
\hline Public consumption expenditure & 17.7 & 17.8 & 18.7 & 19.4 & 19.6 & 19.6 & 19.6 & 19.6 \\
\hline Taxes on production and imports (growth) & 22.3 & 1.6 & -8.5 & 3.3 & 4.4 & 6.7 & 6.6 & 6.6 \\
\hline Current taxes on income, wealth, property (growth) & 40.2 & 1.8 & -8.7 & 3.5 & 6.1 & 6.2 & 6.5 & 6.6 \\
\hline Import growth & 15.2 & 12.7 & -25.3 & 5.0 & 6.3 & 6.5 & 6.8 & 7.1 \\
\hline Nominal GDP growth & 8.0 & 8.6 & 1.3 & 2.5 & 5.0 & 5.9 & 6.1 & 6.2 \\
\hline \multirow[t]{2}{*}{ GDP (billions of euros) } & 15.6 & 16.9 & 17.1 & 17.6 & 18.5 & 19.6 & 20.7 & 22.0 \\
\hline & \multicolumn{8}{|c|}{ Adjustment Scenario 3/ } \\
\hline Total Revenue & 46.4 & 44.9 & 42.6 & 42.6 & 42.7 & 42.8 & 42.8 & 42.8 \\
\hline Total Expenditure & 42.9 & 44.0 & 46.2 & 45.1 & 44.1 & 43.5 & 43.0 & 42.4 \\
\hline Overall balance & 3.4 & 0.9 & -3.8 & -3.2 & -2.2 & -1.5 & -0.9 & -0.3 \\
\hline Structural balance & 2.9 & 0.3 & -3.7 & -2.5 & -1.4 & -0.9 & -0.4 & 0.0 \\
\hline Public debt & 59.4 & 49.4 & 52.6 & 52.8 & 52.5 & 51.1 & 49.0 & 46.5 \\
\hline
\end{tabular}

Sources: Ministry of Finance; and IMF staff estimates.

1/ Consolidates central government budget; public loans fund; social security funds; sinking funds; and defence fund.

2/ Excludes intragovernmental debt and short-term liabilities of the Central Bank.

3 / Adjustments required to reach medium-term structural balance (implies an average reduction of 1/2-3/4 percent of GDP a year). 


\section{INTERNATIONAL MONETARY FUND \\ CYPRUS}

\section{Staff Report for the 2009Article IV Consultation-Informational Annex}

Prepared by the Staff Representatives for the 2009 Consultation with Cyprus

Approved by Ajai Chopra and Ranil Salgado

July 21, 2009

Contents Page

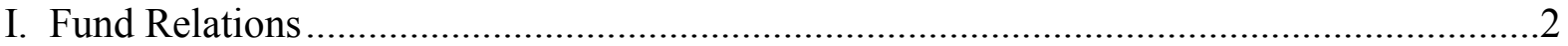

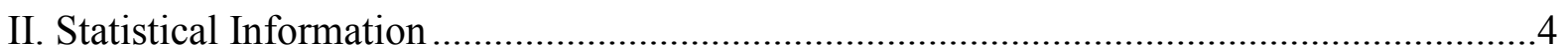




\section{ANNEX I. CYPRUS: FUND RELATIONS}

(As of June 30, 2009)

\section{A. Fund Relations}

I. Membership Status: Joined 12/21/1961;

Article VIII

II. General Resources Account:

Quota

Fund holdings of currency

SDR Million

139.60

122.17

17.47

III. SDR Department:

Net cumulative allocation

Holdings
SDR Million

19.44

1.74
Percent Quota

100.00

87.51

12.52

Percent Allocation

100.00

8.96

IV. Outstanding Purchases and Loans: None

V. Financial Arrangements: None

VI. Projected Obligations to Fund (SDR million; based on existing use of resources and present holdings of SDRs):

\begin{tabular}{lccccc}
\hline & \multicolumn{5}{c}{ Forthcoming } \\
\cline { 2 - 6 } & 2009 & 2010 & 2011 & 2012 & 2013 \\
\hline Principal & & & & & \\
Charges/Interest & 0.03 & 0.07 & 0.07 & 0.07 & 0.07 \\
Total & 0.03 & 0.07 & 0.07 & 0.07 & 0.07 \\
\hline
\end{tabular}

VII. Exchange Rate Arrangement: Cyprus adopted the euro on January 1, 2008. The currency floats freely and independently against other currencies. Cyprus has accepted the obligations of Article VIII, Sections 2, 3, and 4 and maintains an exchange system free of restrictions on the making of payments and transfers for current transactions.

VIII. Article IV Consultation: Cyprus is on a 12-month cycle. The previous Article IV consultation mission took place during October 25-November, 2006, and the staff report (CR/07/76, 2/21/2007) was discussed by the Executive Board on January 26, 2007.

IX. FSAP Participation and ROSCs: An FSAP mission took place during September 23October 6, 2008. The FSAP Technical Notes were published on June 1, 2009 (CR/09/167, $6 / 1 / 2009)$. 


\section{Technical Assistance:}

Dept. Purpose

MAE Government debt management

FAD VAT training program

MAE Financial sector liberalization

MAE Reform of government securities

STA Special Data Dissemination Standard

STA Balance of Payments

STA Balance of Payments

STA Balance of Payments

STA Balance of Payments

FAD Public Investment and PPPs

FAD Medium-term Budget Framework

FAD Medium-term Budget Framework

STA Special Data Dissemination Standard

STA Special Data Dissemination Standard

\section{Date}

February-March 1989

June-October 1992

November-December 1993

April-May 1994

August 1997

March 1999

May-July 2001

November 2001-March 2002

April-June 2002

March-April 2006

May 2006

October 2007

May 2007

March 2009

XI. Resident Representative: None.

XII. Safeguards Assessment: Not Applicable.

XIII. Implementation of HIPC Initiative: Not Applicable.

XIV. Implementation of Multilateral Debt Relief Initiative (MDRI): Not Applicable.

\section{B. Implementation of Fund Policy Recommendations}

Cyprus: Response to Previous Fund Advice

\begin{tabular}{|c|c|c|}
\hline Policy Area & $\begin{array}{l}\text { Staff Recommendation in } 2006 \text { Article IV } \\
\text { Consultation }\end{array}$ & Implementation \\
\hline Macroeconomic Policies & $\begin{array}{l}\text { Ensure continued observance of Maastricht } \\
\text { criteria and smooth adoption of euro. }\end{array}$ & Euro adopted on January1, 2008. \\
\hline Fiscal Policy & $\begin{array}{l}\text { For } 2007 \text {, respect spending limits, save excess } \\
\text { revenue. Objective of budget balance by } 2010 \\
\text { should be met through checks on current } \\
\text { expenditures. Supplementary budgets should be } \\
\text { banned. Implement pension and health care } \\
\text { reform. }\end{array}$ & $\begin{array}{l}\text { Spending limits respected in } 2007 \text {, excess } \\
\text { revenues saved. No supplementary budgets. } \\
\text { However, current spending increased in } 2008 \text {. } \\
\text { Pension reform enacted but measures are } \\
\text { mostly revenue-based. Healthcare reform } \\
\text { delayed due to a lack of consensus and } \\
\text { technical factors. }\end{array}$ \\
\hline Financial Sector Policy & $\begin{array}{l}\text { Monitor credit and house price developments to } \\
\text { contain financial sector risks. Strengthen financial } \\
\text { supervision by unifying supervision, improving } \\
\text { resources and independence, completing FSAP. }\end{array}$ & $\begin{array}{l}\text { FSAP completed. Supervision improved in line } \\
\text { with EU directives and FSAP } \\
\text { recommendations. Stress testing framework } \\
\text { introduced and monitoring improved. }\end{array}$ \\
\hline Structural Policies & $\begin{array}{l}\text { Implement National Lisbon Program. Redesign } \\
\text { wage-setting by aligning real wage growth to } \\
\text { productivity developments. Improve competition. }\end{array}$ & $\begin{array}{l}\text { The National Reform Programme is being } \\
\text { implemented but slowly. Wage increases have } \\
\text { continued to outstrip productivity especially in } \\
\text { the manufacturing and public sector. }\end{array}$ \\
\hline
\end{tabular}




\section{ANNEX II. CYPRUS: STATISTICAL INFORMATION}

As of July 14, 2009

\section{A. Assessment of Data Adequacy for Surveillance}

General: Data provision is adequate for surveillance.

National Accounts: The transition to the new European System of Accounts 1995 (ESA 1995) has complicated the analysis of national accounts and fiscal data. The new national accounts do not provide information on the disposable income of households, thus hindering the calculation of the household saving ratio.

Financial sector data: The currency-linked and indexed bonds held by nonresidents are classified as domestic instead of foreign liabilities.

External debt: The authorities have recently decided to include non-resident deposits in resident banks in gross external debt.

Other: Data on property prices and household sector assets do not exist.

\section{B. Data Standards and Quality}

Cyprus is planning to subscribe to the IMF's Special Data Dissemination Standard (SDDS) shortly. No data ROSC is available. 


\section{Cyprus: Table of Common Indicators Required for Surveillance (As of July 14, 2009)}

\begin{tabular}{|c|c|c|c|c|c|}
\hline & $\begin{array}{l}\text { Date of latest } \\
\text { observation }\end{array}$ & $\begin{array}{l}\text { Date } \\
\text { received }\end{array}$ & $\begin{array}{l}\text { Frequency } \\
\text { of Data }^{7}\end{array}$ & $\begin{array}{l}\text { Frequency of } \\
\text { Reporting }\end{array}$ & $\begin{array}{l}\text { Frequency of } \\
\text { Publication }^{7}\end{array}$ \\
\hline Exchange Rates & Current & Current & $\mathrm{D}$ & $\mathrm{D}$ & $\mathrm{D}$ \\
\hline $\begin{array}{l}\text { International Reserve Assets and } \\
\text { Reserve Liabilities of the } \\
\text { Monetary Authorities }\end{array}$ & May 2009 & Jun 2009 & M & M & M \\
\hline Reserve/Base Money & Dec 2007 & Jan 2008 & M & M & M \\
\hline Broad Money & Dec 2007 & Jan 2008 & M & M & $\mathrm{M}$ \\
\hline Central Bank Balance Sheet & Dec 2007 & Jan 2008 & M & M & M \\
\hline $\begin{array}{l}\text { Consolidated Balance Sheet of } \\
\text { the Banking System }\end{array}$ & Dec 2007 & Jan 2008 & M & M & M \\
\hline Interest Rates $^{2}$ & May 2009 & Jun 2009 & M & M & $\mathrm{M}$ \\
\hline Consumer Price Index & May 2009 & Jun 2009 & M & M & M \\
\hline $\begin{array}{l}\text { Revenue, Expenditure, Balance } \\
\text { and Composition of Financing }{ }^{3}- \\
\text { General Government }^{4}\end{array}$ & Q4 2008 & Apr 2009 & Q & Q & Q \\
\hline $\begin{array}{l}\text { Revenue, Expenditure, Balance } \\
\text { and Composition of Financing }{ }^{3}- \\
\text { Central Government }\end{array}$ & Q4 2008 & Apr 2009 & Q & Q & Q \\
\hline $\begin{array}{l}\text { Stocks of Central Government } \\
\text { and Central Government- } \\
\text { Guaranteed Debt }\end{array}$ & Q4 2008 & Apr 2009 & Q & $\mathrm{Q}$ & Q \\
\hline $\begin{array}{l}\text { External Current Account } \\
\text { Balance }\end{array}$ & Q4 2008 & Apr 2009 & Q & Q & Q \\
\hline $\begin{array}{l}\text { Exports and Imports of Goods } \\
\text { and Services }\end{array}$ & Q4 2008 & Apr 2009 & Q & Q & Q \\
\hline GDP/GNP & Q1 2009 & Jun 2009 & $\mathrm{Q}$ & $\mathrm{Q}$ & $\mathrm{Q}$ \\
\hline Gross External Debt & Q4 2008 & Jun 2009 & Q & Q & Q \\
\hline $\begin{array}{l}\text { International Investment } \\
\text { Position }^{6}\end{array}$ & 2008 & Jun 2009 & A & A & A \\
\hline
\end{tabular}

1 Any reserve assets that are pledged of otherwise encumbered should be specified separately. Also, data should comprise short-term liabilities linked to a foreign currency but settled by other means as well as the notional values of financial derivatives to pay and to receive foreign currency, including those linked to a foreign currency but settled by other means. 2 Both market-based and officially-determined, including discount rates, money market rates, rates on treasury bills, notes and bonds.

3 Foreign, domestic bank, and domestic nonbank financing.

4 The general government consists of the central government (budgetary funds, extra budgetary funds, and social security funds) and state and local governments.

5 Including currency and maturity composition.

6 Includes external gross financial asset and liability positions vis-à-vis nonresidents.

7 Daily (D); weekly (W); monthly (M); quarterly (Q); annually (A); irregular (I); and not available (NA). 


\section{INTERNATIONAL MONETARY FUND}

EXTERNAL

Public Information Notice (PIN) No. 09/108

FOR IMMEDIATE RELEASE

August 17, 2009
International Monetary Fund

$70019^{\text {th }}$ Street, NW

Washington, D. C. 20431 USA

\section{IMF Executive Board Concludes 2009 Article IV Consultation with Cyprus}

On August 5, 2009 the Executive Board of the International Monetary Fund (IMF) concluded the 2009 Article IV consultation with Cyprus. ${ }^{1}$

\section{Background}

The global crisis is beginning to affect Cyprus. The economy has been relatively shielded from the crisis so far, recording positive growth in the first quarter of 2009, well above the euro area. The financial sector has not required public capital injections. The relative resilience is due to the elimination of exchange rate risk following euro adoption, conservative financial sector practices with limited exposure to toxic assets and strict supervision, and a domestic demand-based growth with less reliance on manufacturing exports. However, the economy is beginning to slow in response to the global crisis. Growth is projected to fall sharply to $1 / 3$ percent in 2009 as banks and the private sector restructure balance sheets. On current policies, a tepid but uncertain recovery is expected to begin starting 2010.

Despite its resilience so far, the economy is slowing down and risks are increasing. The overheating of the economy in 2007-08 has left the private sector highly leveraged, and banks and households exposed to the property market. The expected slowdown will increase credit risk in banks, which, in some plausible but unlikely extreme scenarios, could have systemic implications given the size and concentration of the banking sector. The government and the Central Bank of Cyprus (CBC) have taken action to ensure the soundness of the banking system. There has been significant progress in implementing EU Directives and recommendations made by the recent Financial Sector Assessment Program (FSAP). In particular, deposit insurance coverage and funding has increased; a crisis management law is being drafted to empower the government to preemptively address liquidity or insolvency

${ }^{1}$ Under Article IV of the IMF's Articles of Agreement, the IMF holds bilateral discussions with members, usually every year. A staff team visits the country, collects economic and financial information, and discusses with officials the country's economic developments and policies. On return to headquarters, the staff prepares a report, which forms the basis for discussion by the Executive Board. At the conclusion of the discussion, the Managing Director, as Chairman of the Board, summarizes the views of Executive Directors, and this summary is transmitted to the country's authorities. 
problems; and a legal and regulatory framework for covered bonds has been initiated to facilitate the availability of refinancing under the ECB's facilities. Nevertheless bank soundness indicators are being adversely affected by the economic environment.

Large current account deficits partly indicate competitiveness problems especially in the manufacturing and tourism sectors. In particular, the backward-looking automatic indexation mechanism (COLA) has recently contributed to wages outstripping productivity increases. The external position would therefore be vulnerable if the current sources of financing-foreign direct investment and non-resident deposit flows into the banking system-were to decline. While there has been progress - albeit slow_in implementing the wide-ranging structural reforms of the government's National Reform Programme, reforming the COLA is not part of the agenda at this juncture.

The largely revenue-based fiscal consolidation has started unwinding. This is due to softening growth, the lapse of temporary revenue-generating factors, and increases in untargeted social spending starting 2008. Although important pension reforms were recently enacted, they rely mainly on contribution increases and do not yet fully address the large ageing-related increases in pension expenditures. Fiscal policies could potentially become unsustainable if current policies, which significantly increase the inelastic component of budget spending (especially payroll), are implemented.

\section{Executive Board Assessment}

The Executive Directors noted that Cyprus has weathered the crisis well. The overheating of the economy in 2007-08 has given rise to certain risks that would need to be managed carefully as the economy slows. Policies would need to mitigate short-term risks while ensuring mediumterm sustainability.

Directors endorsed the government's objective to achieve a balanced budget over the medium term. They noted that, based on strengthened policies, the budget deficit will need to decline by about $1 / 2-3 / 4$ percent of GDP a year with a significant upfront correction to avoid unfavorable debt-deficit dynamics going forward. Directors emphasized that fiscal adjustment should rely on reducing public consumption, particularly the wage bill, and on broader public administration reforms. They considered that the temporary stimulus measures should be allowed to expire once the recovery sets in, and the social support measures should be carefully targeted to the needy. Directors welcomed the passage of pension reforms. A few Directors considered that additional pension reforms may be necessary in future, including raising the retirement age and better aligning public and private benefits.

Directors recommended the adoption of a medium-term budget framework and more effective management of public sector liabilities. The government's recent initiative in this area could be further enhanced by monitoring contingent liabilities and minimizing the possibility of moral hazard and adverse selection in public sector aid programs. 
Directors were reassured that financial sector risks appear to be manageable. Nonetheless, given the size and concentration of the financial sector, they expressed concern that problems can potentially become systemic, underscoring the importance of early detection of risks and intervention to preserve financial sector stability. They encouraged the Central Bank of Cyprus (CBC) to enhance monitoring of banks' funding, cross-border exposures, and counterparty risk management. With the potential for a further deterioration in asset quality, the CBC should require higher capital buffers, particularly from systemically-important banks.

Directors recommended that supervision and the safety net be further improved over the medium term. They noted that Cyprus' reputation as a financial center relies on continued effective supervision by an independent and accountable central bank. In the view of most Directors, a single supervisor for all credit institutions and a more integrated supervisory structure in the CBC should be considered. The stress-testing framework should be enhanced and supervisory and financial stability resources bolstered. Directors welcomed Cyprus' participation in a Financial Sector Assessment Program (FSAP), and called for implementation of its recommendations.

Directors underlined the importance of improving competitiveness to assist the recovery and support external viability. They encouraged the authorities to reverse the deterioration in productivity and unit labor costs by implementing the broad-ranging National Reform Program, including cutting red tape, streamlining the bureaucracy, and implementing other structural reforms. Directors supported eliminating the automatic wage indexation mechanism (COLA) or mitigating its impact through productivity improvements and better targeting.

Public Information Notices (PINs) form part of the IMF's efforts to promote transparency of the IMF's views and analysis of economic developments and policies. With the consent of the country (or countries) concerned, PINs are issued after Executive Board discussions of Article IV consultations with member countries, of its surveillance of developments at the regional level, of post-program monitoring, and of ex post assessments of member countries with longer-term program engagements. PINs are also issued after Executive Board discussions of general policy matters, unless otherwise decided by the Executive Board in a particular case. The staff report (use the free Adobe Acrobat Reader to view this pdf file) for the 2009 Article IV Consultation with the Cyprus is also available. 
Cyprus: Selected Economic Indicators, 2005-09

(Annual percentage change, unless otherwise indicated)

$20052006 \quad 2007 \quad 2008 \quad 20091 /$

Real economy

Gross domestic product

Domestic demand (contribution to annual growth)

Harmonized index of consumer prices (period average)

Unemployment rate (percent)

Public finances (general government, percent of GDP)

Overall balance

Primary balance

Gross public debt 2/

Interest rates (percent)

Deposit rates 3/

Lending rates $4 /$

Balance of payments (percent of GDP)

Trade balance

Current account balance

Fund Position (June 30, 2009)

Holdings of Currency (percent of quota)

Holdings of SDR's (percent of allocation)

$\begin{array}{rrrrr}3.9 & 4.1 & 4.4 & 3.6 & 0.3 \\ 3.2 & 5.7 & 7.7 & 9.3 & -2.7 \\ 2.0 & 2.2 & 2.2 & 4.4 & 0.9 \\ 5.3 & 4.6 & 3.9 & 3.7 & 5.6\end{array}$

Quota (millions of SDR)

Exchange rates

Exchange rate regime

Present rate (July 13, 2009)

Nominal effective exchange rate (CPI, 2000 $=100) 5 /$

$\begin{array}{lllll}-2.4 & -1.2 & 3.4 & 0.9 & -3.9\end{array}$

$\begin{array}{lllll}1.1 & 2.1 & 6.5 & 3.8 & -1.5\end{array}$

$\begin{array}{lllll}69.1 & 64.6 & 59.4 & 49.4 & 52.7\end{array}$

Real effective exchange rate $(C P I, 2000=100) 5 /$

$\begin{array}{rrrrr}3.7 & 3.6 & 4.4 & 5.4 & 3.3 \\ 6.7 & 6.8 & 6.3 & 7.0 & 6.9 \\ & & & & \\ -25.4 & -27.7 & -30.3 & -32.8 & -26.6 \\ -5.9 & -7.1 & -11.8 & -18.3 & -10.3\end{array}$

87.5

Euro Area Member

US\$ 1.44 per euro

$\begin{array}{lllll}100.0 & 100.5 & 101.2 & 104.7 & 106.2\end{array}$

$\begin{array}{lllll}100.0 & 100.2 & 100.2 & 103.8 & 104.9\end{array}$

Sources: Ministry of Finance; Central Bank; World Bank, World Development Indicators; and IMF staff estimates.

1/ Data for 2009 are projections.

2/ Excludes intragovernmental debt and short-term liabilities of the Central Bank.

3 / Since 2007, data refer to the average of MFI interest rates on euro-denominated deposits up to 1 year. Data for 2009 are as of May.

4/ Since 2007, data refer to the average of MFI interest rates on euro-denominated loans. Data for 2009 are as of May.

5/ Data for 2009 are as of April. 


\section{Statement by Age Bakker, Executive Director for Cyprus and Tomislav Galac, Advisor to Executive Director August 5, 2009}

The Cypriot economy has performed well amidst the global financial and economic crisis. The financial sector has been little affected by the contraction of global liquidity and the increase in risk aversion. This can be mostly attributed to a positive effect of the EMU entry at the beginning of 2008, to tight banking regulation and supervision, and to traditionally conservative business models of Cypriot banks, which account for about eighty percent of the total financial system assets. The real sector has also shown resilience against the slumping external demand and tightening of financing conditions. This was mostly due to continued strong domestic demand, driven by still robust employment, wage growth, and credit growth.

With this backdrop, the authorities held constructive discussions with the Fund team led by Ms. Banerji during its stay in Nicosia in June 2009. The Cypriot authorities value their continuing cooperation with the International Monetary Fund, and given the relative importance of Cyprus as an international financial center, they welcome the continuation of the Article IV cycle on a twelve month basis. The authorities especially welcome the thorough staff analysis produced by the Fund team during the 2009 Article IV Consultations with Cyprus and offer the following comments for the Executive Board discussion.

\section{Recent Economic Developments and Prospects}

While there was a modest reduction in the tourism revenue in 2008, and the construction sector weakened towards the end of the year, private consumption remained at satisfactory levels, the important business services sector was moderately affected, and health and education services as well as public investment recorded a significant growth during the year. Overall, during 2008, the economy recorded real growth of 3.7 percent, slightly down from the 4.1 average of recent years, while the unemployment rate has reached a record low level of 3.7 percent. The relatively high consumer price inflation of 4.4 percent for the year and record high current account deficit of 18.3 percent of GDP, can be mainly attributed to the energy and food price developments in the first half of the year. Buoyant private consumption boosted imports and contributed also significantly to the widening of the current account.

Looking ahead, Cyprus is the only EU economy expected to record positive economic growth in 2009, although there are downside risks. However, all the leading indicators of economic activity point to a deceleration of growth, that may persist throughout next year. The extent of the slowdown will depend on the effectiveness of the sizable fiscal stimulus that the authorities have been undertaking since the second half of 2008. Equally important will be the global and regional economic and financial developments, as well as those in the Euro zone, the UK, and Russia - the most important markets for Cypriot exports and capital inflows. A downside risk for growth in the short run may be posed by the recently widening interest rate spreads in Cyprus relative to their EMU benchmarks, both on deposits and on loans. The authorities are also continuously monitoring energy and food prices, since both consumer prices and current account developments in Cyprus are very sensitive to those two external factors. 
In the central scenario, the authorities now expect real growth between 0.4 and 1.0 percent, both in 2009 and 2010, with a significant improvement in the trade deficit in the period 2009-11, on account of significantly lower imports. Lower expected imports are primarily related to food and energy, due to their lower prices, and to large-ticket durable consumer goods, due to a lower domestic credit growth. The most recent Fund forecast is for a growth of 0.3 percent in 2009, and 1.0 in 2010, not far off the authorities' mark. The main contribution to growth in the short term will come from public spending and investment, and from an improvement in net exports. Business services are also anticipated to perform well, while revenues in tourism and construction are expected to decline markedly. In these circumstances, the authorities expect unemployment to rise to between 5 and $5 \frac{3}{4}$ percent in 2009 and 2010. In the medium term, the authorities expect the economy to return to the path of average growth of about 3 percent per year, supported by a further diversification of the strong services sector.

The authorities expect an increase in non-performing assets in the banking sector in 2009 and 2010 which will be more pronounced in lending to enterprises in the disproportionately affected sectors. In lending to households, traditional reliance on a family-provided safety net, secure employment, and overcollateralization should lead to minimal loan losses. However, declining rates of credit growth will eat into banks' profit margins. As an early indication, bank and credit cooperatives' profits have halved in the first quarter of 2009 relative to the same period a year ago. Nevertheless, given the strong initial position of the financial sector, and the relative strength of the economy, the authorities do not envisage an alarming rise in system-wide risks due to the anticipated short-term economic developments. Such an assessment is confirmed by the top-down and bottom-up bank stress tests carried out by the central bank for the years ended in 2007 and 2008, also verified by the Fund during the October 2008 FSAP and the current Article IV consultation. The mitigating factors in the household lending segment should also shield the credit cooperatives which lend only to households, and hold the remaining twenty percent of domestic deposits in Cyprus. In addition, the banks have recently raised fresh capital to prepare for the anticipated rise in loan losses.

\section{Economic Policies}

In this environment, given the relatively low level of public debt (below 50 percent of GDP at end-2008), and the strong initial conditions and recent performance of the financial sector, the authorities intend to pursue anti-cyclical fiscal and financial sector policies. In the fiscal area, full operation of automatic stabilizers will be allowed while the discretionary measures will focus on supporting tourism, on additional spending on vulnerable groups, and especially on small scale local investment in infrastructure, to support employment in the heavily affected construction sector. The total budgetary impact of the 2009 fiscal stimulus is estimated at a cost of 1.5 percent of GDP. With the revenues also falling short of projections, the authorities now expect the general government shortfall in 2009 and 2010 of the order of 2.5 to 3.0 percent of GDP, and will do everything possible to constrain the deficit-to-GDP ratio from exceeding the 3 percent level. On the other hand, the authorities will also watch for the possible lagged positive effects from the Euro area and UK stimuli, and from catching-up of domestic interest rates with the lower EMU level, and adjust domestic policies accordingly. 
The authorities have recently adopted one important piece of legislation while working on two others that should further strengthen the liquidity, confidence, and crisis management capacity in the financial sector. The first concerns the new regulations governing the operation of the two deposit insurance schemes, which have quintupled the coverage to 100,000 euro, removed the $10 \%$ coinsurance clause, and have covered deposits in all currencies, both for commercial banks and for credit cooperatives, in line with EU legislation. The second legislation, still in draft form, concerns the crisis management law which should allow the government to take decisive but temporary action in a low probability case of liquidity or solvency problems in individual locally incorporated credit and other financial institutions without prior Parliamentary approval. Third, the covered bond draft law and the related changes to other pieces of legislature are being discussed in order to improve the access of Cypriot banks to the ECB liquidity facilities.

Additionally, the authorities are in the process of analyzing and implementing recommendations of the recent FSAP mission by the IMF, and a number of recommendations have already been implemented, especially those related to transparency, and corporate governance in the financial sector. Moreover, the authorities intend to further improve the financial regulation framework immediately following the conclusion of the ongoing EUwide discussions on the regulation of credit rating agencies, alternative and collective investment schemes, and others. Finally, the cooperation among the domestic supervisory agencies has further strengthened in practice. For example, since May, the Central Bank of Cyprus and the Authority for the Supervision and Development of Cooperative Societies have begun carrying out joint on-site supervision of cooperatives, and all supervisory agencies cooperated in designing the corporate governance code of conduct for financial intermediaries.

\section{Structural Reforms}

While the authorities are now focused on mitigating the effects of the global economic crisis, they continue to work diligently on pursuing their national reform program pursuant to the Lisbon agenda. Most notably, the Social Security Fund reform package was adopted by the Parliament in April, securing the financial sustainability of the social pension scheme until 2050. The reform includes both increased contributions and stricter eligibility criteria for enjoying the benefits provided by the scheme. While the Government and social partners recognize that demographic pressures will persist in the very long run, they consider that the recent reforms have settled the issue for a considerable period, and stress that the authorities must now give attention to other key issues, such as healthcare reforms. Indeed, the complex process of decentralization of the public health system has been progressing slower than envisaged. In addition, the national life-long learning strategy is being implemented to meet the demands of the dynamic labor market. To support further growth and diversification of the economy, major infrastructure investments are currently being implemented, including a new airport, and water desalination plants.

\section{Conclusion}

Against the above background, the authorities are confident that Cyprus will maintain its position as a competitive principal international financial center, and a well-diversified service-oriented economy. Moreover, they believe that its internationally recognized 
advantages - the low tax burden, strong legal and institutional base, skilled and multilingual labor, strategic location, and proactive business-friendly government policies - will not only keep supporting competitiveness in these areas, but will allow the economy to diversify further. Recent successes in health and education tourism are the first steps in this direction. 